
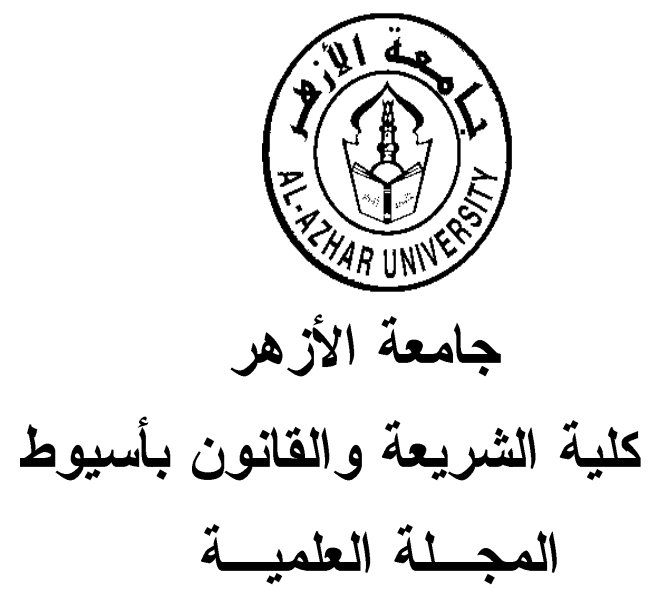

\title{
جرائم الجلسات
}

$$
\text { إعداد }
$$

\section{د/ حمان بن دروشّ الفامدي}

أستاذ القانون المشارك - المشرف على وحدة بحوث الأنظمة و القانون

$$
\text { قدم البحوث الإدارية والإنسانية }
$$

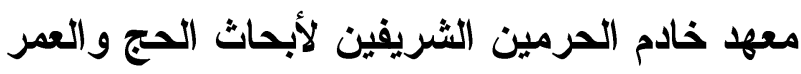

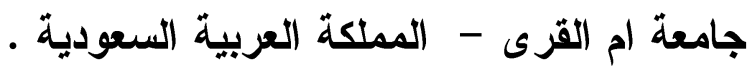

( العدد الرابع والثلاثون الإصدار الأول يناير r r • ب م الجزء الثاني ) 


\section{جرانم البلسات}

حمدان بن درويش الغامدي. قسم البحوث الإدارية والإنسانية، معهد خادم الحرمين الثريفين لأبحــاث الحــج والعمرة، جامعة أم القرى، المملكة العربية السعودية. البريد الإكتروني: HDGHAMDI@UQU.EDU.SA هفمص البمث: مما لا شكك فيه أن هيبة القضاء واحترامه من هيبة الدولة، فالقضاء هو سـلطة من سلطات الدولة التي تحمي النظام وتحافظ عليه، فهو الملاذ الوحيد لرد الحقوق

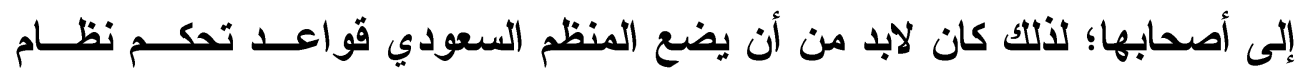
الجلسات التي تنظر فيها قضايا المختصمين، سواء أكانت قضايا مدنية أم جنائية؛

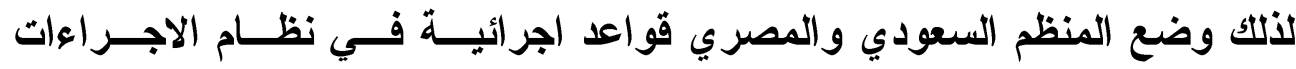

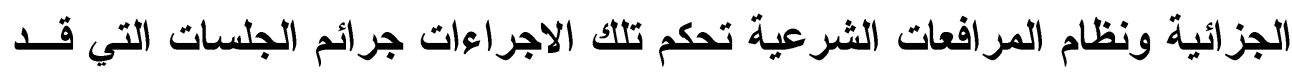
تقع من المتواجدين في الجلسة، كذلك أعطى المنظم الحق فــي بعــ الأحسـوال لبعض المحاكم بصفة استثنائية أن تقوم بتحريك الاعوى الجنائية مباثــرة دون لـون اللجوء إلى التيابة العامة المختصة أصلا بتحريكها، وذلك في حالة الإخلال بنظــام الجلسة المنوط بضبطها رئيسها، أو التعدي على أحد أعضاء هيئة المحكمــة، أو إوله ارتكاب أي فعل يشكل جريمة في النظام، وكان الههف من ذلك هو المحافظة على هيبة القضاء، ونجد أن المنظم السعودي لم يعطي هذا الحق الاستثنائي إلى جميع

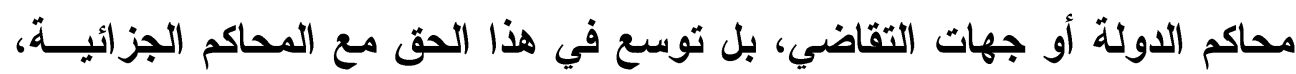

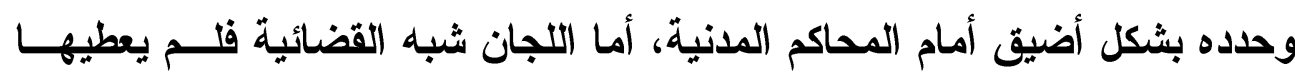
المنظم السعودي الحق في تحريك الاعوى الجزائية في شأن ما قد يقع أمامها من 
جرائم أثناء نظر الدعوى، ومن أهم النتائج: أن المنظم السعودي استثنى جـرائم

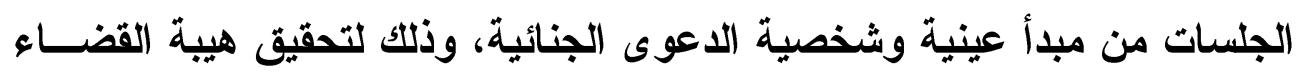
وإعطائه الاحترام الواجب، لم يستثني المنظم السعودي المحامين من أحكام جرائم

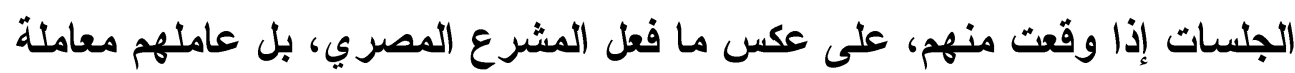

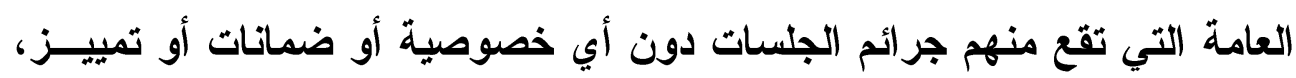

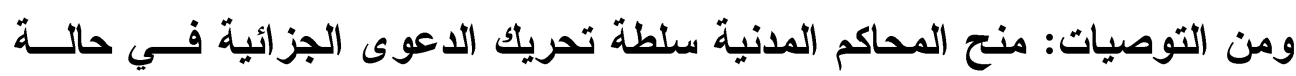
وقوع جريمة تعدي على هيئتها أو على أحد أعضائها، ومعاملة المحكمة المدنيـــة في هذا الثأن معاملة المحاكم الجزائية.

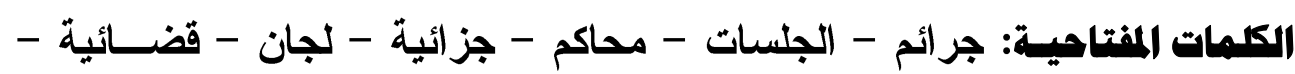
إجراءات - الدعوى. 
Session Crimes at Courts of Law

By Hamdan bin Darweesh Al-Ghamdi,

Department of Humanities and Administrative Research, Custodian of the Two Holy Mosques Institute for Hajj and Umrah Research, Umm Al-Qura University, Makkah AlMukarramah, KSA

HDGHAMDI@UQU.EDU.SA

Abstract

The judiciary is the only recourse to restore rights to their owners; therefore, the Saudi legislator set rules that govern the system of sessions in which the cases of litigants are considered. Both the Saudi and Egyptian legislators set procedural rules in the system of criminal procedures and the legal pleading system to govern the crimes that may be committed by those present at the session. To preserve the prestige of the judiciary, the legislator gave in some cases to some courts, on an exceptional basis, the right to initiate the criminal case directly without resorting to the Public Prosecution. This can happen if the session order is breached, if a crime is committed, or if some of the judiciary are assaulted. This exceptional right has been given extensively to some courts such as the criminal courts, but most of the civil courts have been denied this right. This study recommends that civil courts be given the same exceptional right as the criminal courts.

Key words: crimes - session - courts - criminal - committees - judicial - measures - case. 


\section{مقدمة}

الأصل أن الدعوي الجزائية متى دخلت في حوزة القضاء، فإن سلطته تقتصر

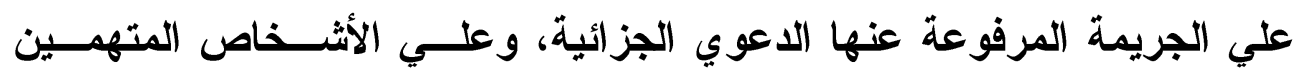

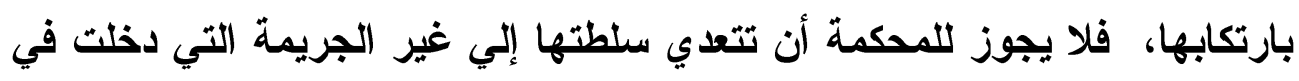

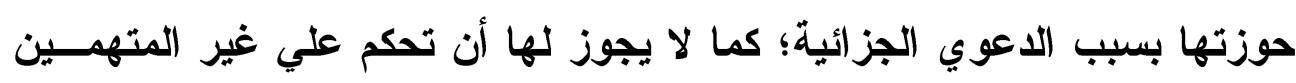

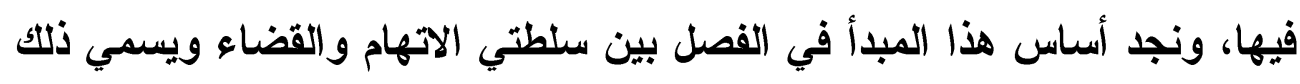
بمبلأ عينية الاعوي وشخصيتها.

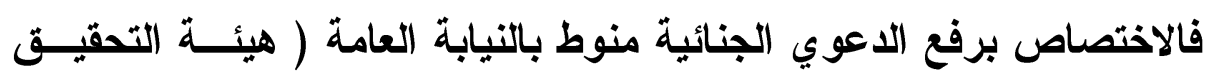

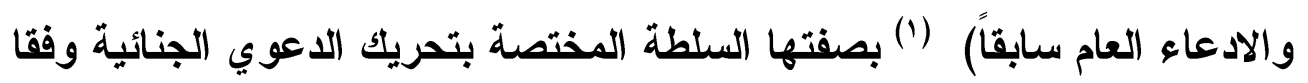

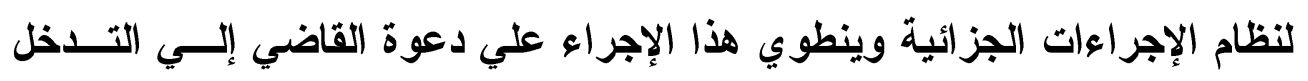

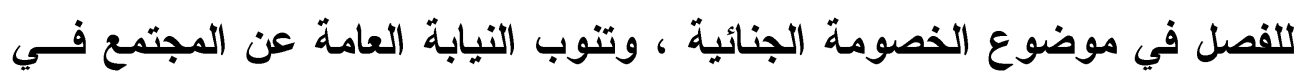

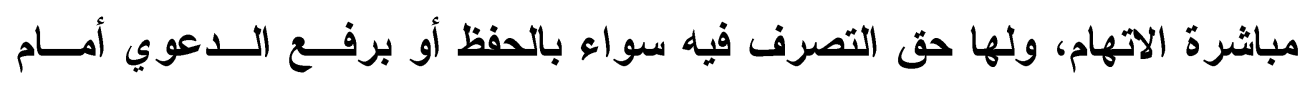

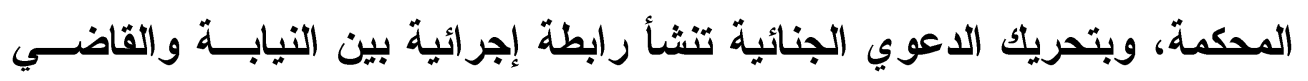

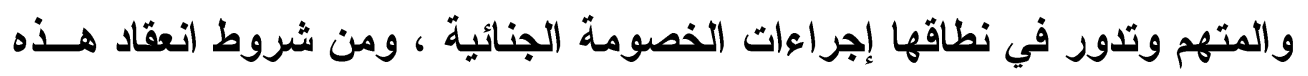

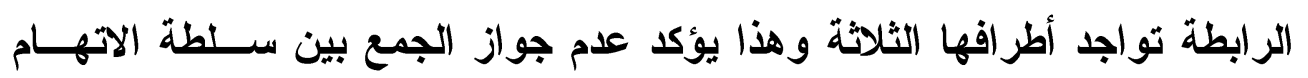
و الحكم في شخص واحد. والاستثناء على هذه القاعدة تأخذ به العديد من الأنظمة ، فقد أعطي المشرع

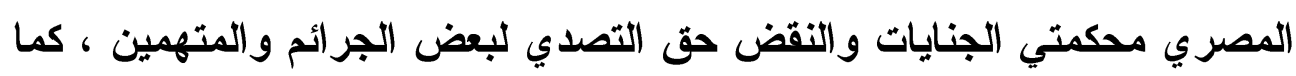

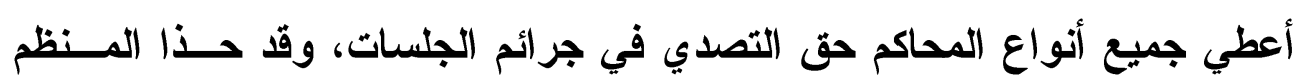

(1) راجع المادة 10 من نظام الإجراءات الجزائية السعودي 
السعودي حذو المشرّع المصري في مبدأ عينية الــــعوي الجنائيــة والاســثناء

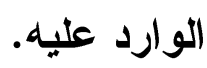

فقد نصت المادة الخامسة عشر من نظام الإجراعات الجزائية السعودي علي

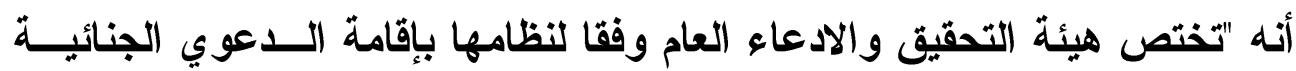

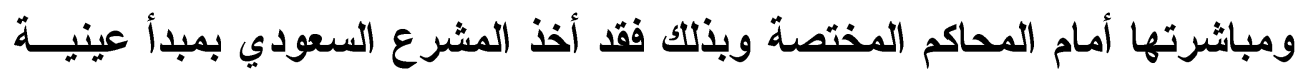

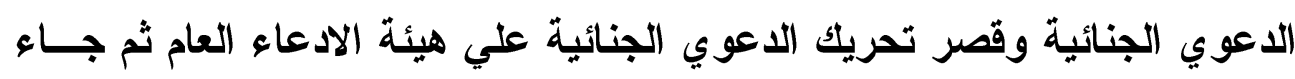

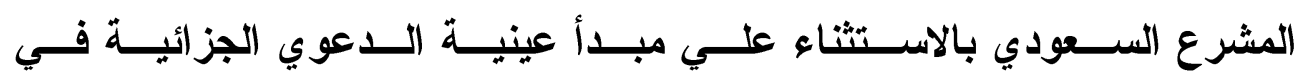

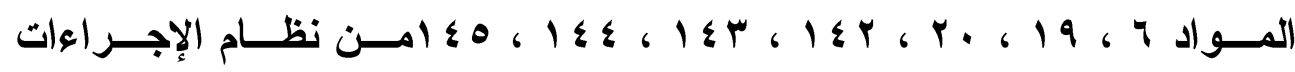

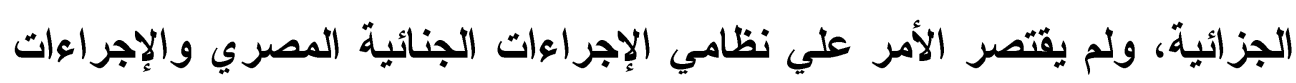

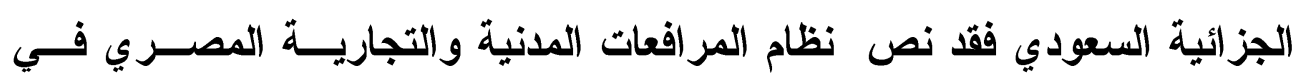

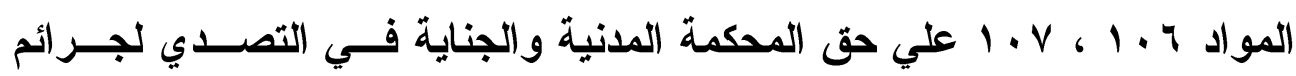

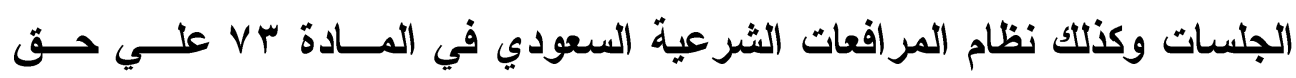
التصدي التصنان وبناء علي ما قرره المنظم المصري والسعودي في كلا النظامين الإجرائسي

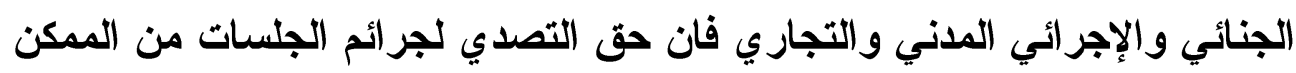

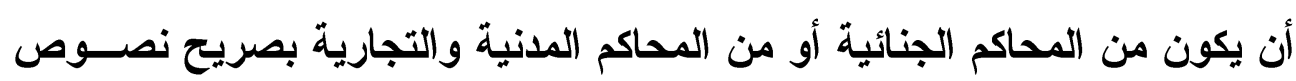
الأنظمة.

إثكالية البمث: الانظمه

تظهر مشكلة البحث في السؤال الذي يطرح نفسه وهو هل يحق للَّبان شبه

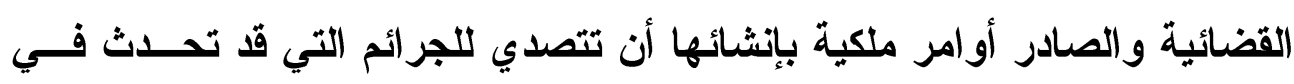

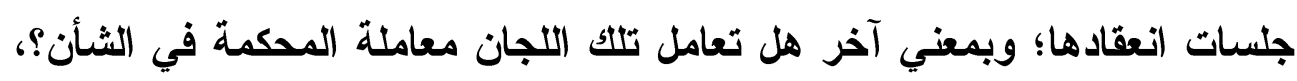


نجيب علي هذا التساؤل من خلال الحديث عن جرائم الجلســات أمسام القاضــي

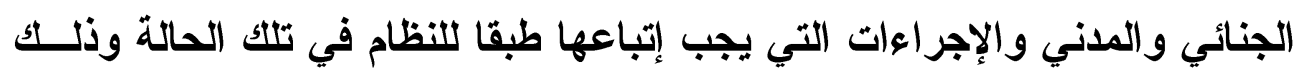
في النظامين المصري و السعودي ووضع الفرضية أمام اللجان شــبه القضـــائية وبيان هل ستعامل تلك اللجان في هذه الحالة معاملة المحاكم أم لا؟ .

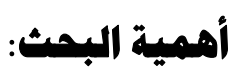

رأى المنظم أن الجرائم التي قد تقع أثناء نظر الاعوى فـــي الجلســـة أمسـام

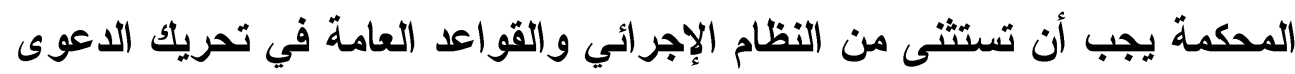

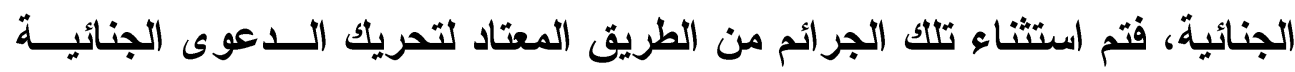

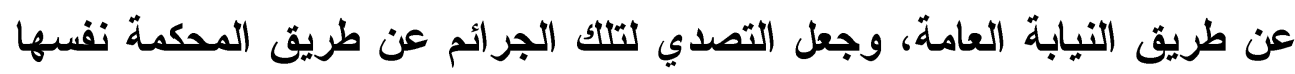

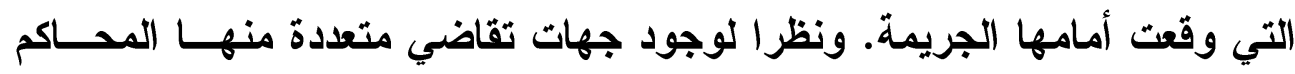

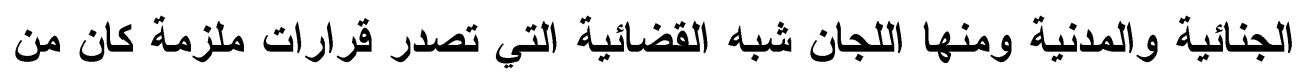

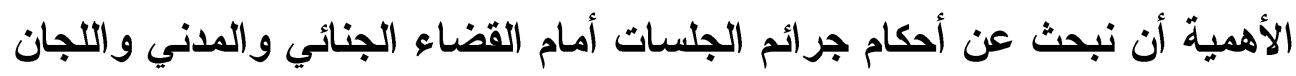

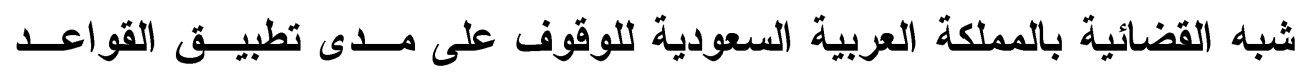

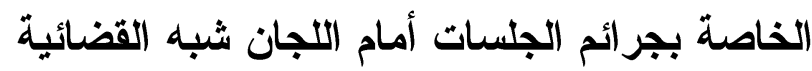
أهداف البحث

يهذف البحث إلى عرض وتحليل أحكام جرائم الجلسات في نظامي الإجراءات

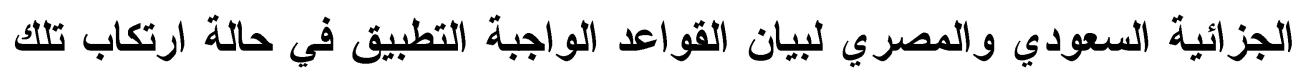

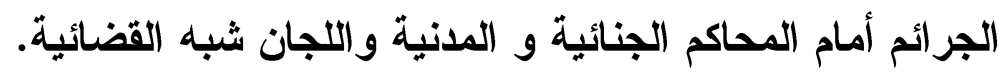

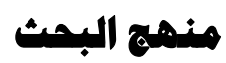

إن إثكالية البحث لها دور رئيس في اختيار المنهج الذي يجب إتباعه فــي

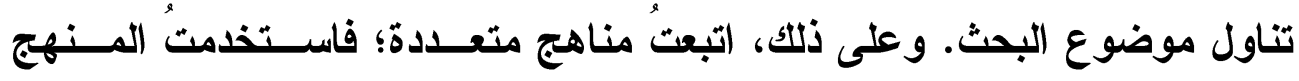


الوصفي من خلال عرض نصوص القوانين و الأنظمة، والوقوف على مكوناتها.

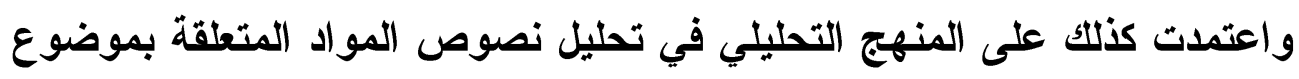

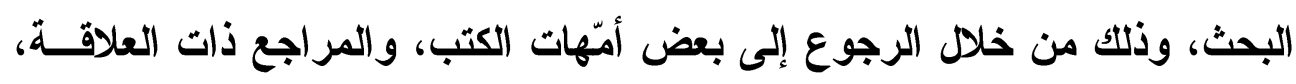

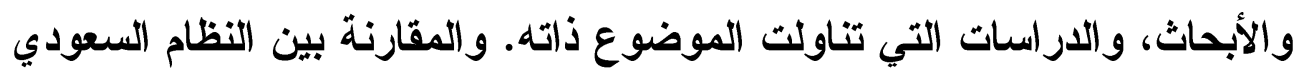
و القانون المصري في موضوع البحث. خطة البمث

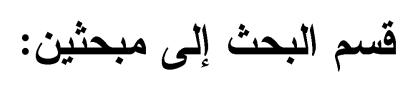

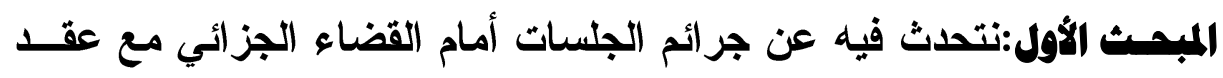
المقارنة بين القانون المصري والنظام السعودي في هذا الثأن.

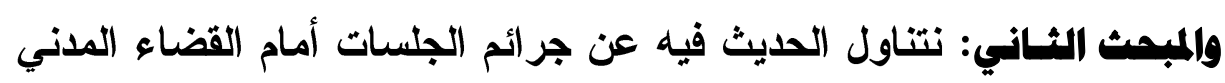
وفرضية وقوع جرائم الجلسات أمام اللجان شبه القضائية في النظام السعودي. 


\section{المبمث الأول \\ أمكام جرانم البلسات أهام القضشاء الجزاني في النظام السعودي والتشريج المصري}

هيبة القضاء و المحاكم بوجه عام ومقتضيات الاحترام الواجب في حضــرتها

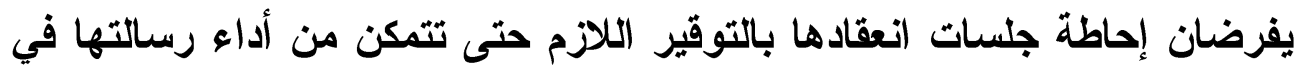

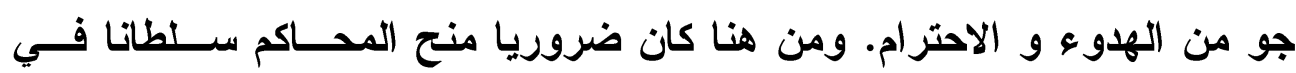

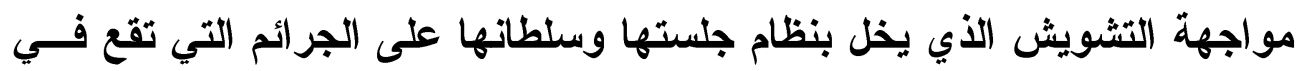

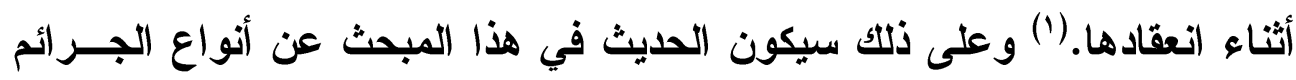

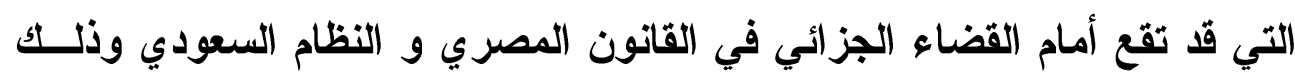

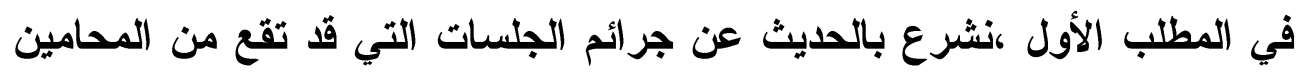
أثناء انعقاد الجلسة وذلك في المطلب الثاني. الامطب الأول الماني

أنواع جرانم البهسات أهام القضاء الجزاني

في القانون المصري والسمودي

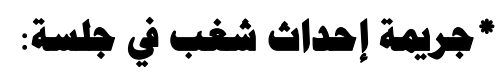
هوقف القانون المصري

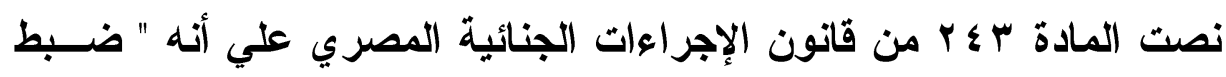

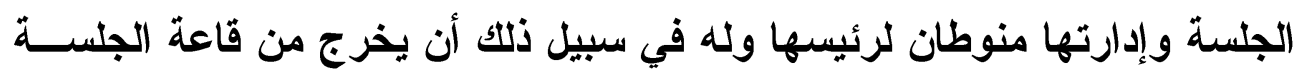

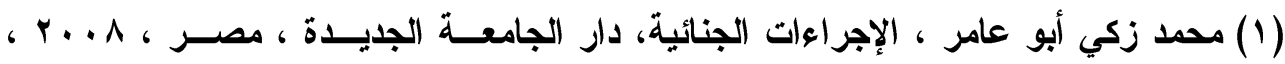

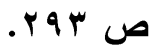


من يخلّ بنظامها ، فإن لم يمتثل وتمادى كان للمحكة أن تحكم بحبسه ؟ ؟ ساعة

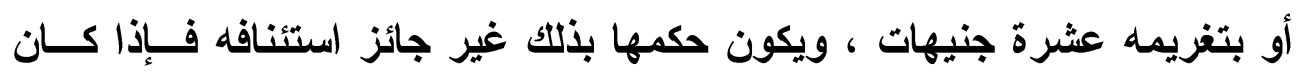

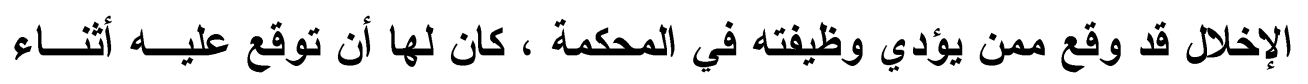

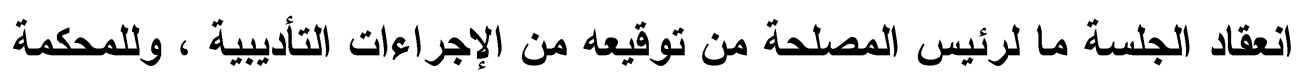

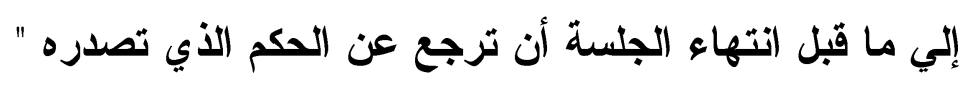

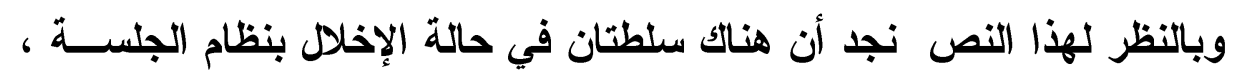

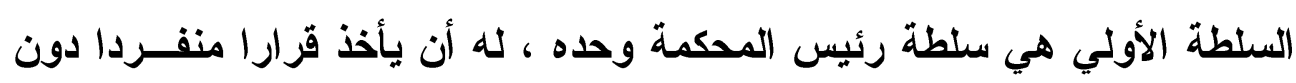

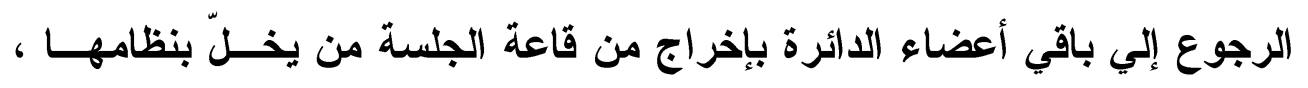

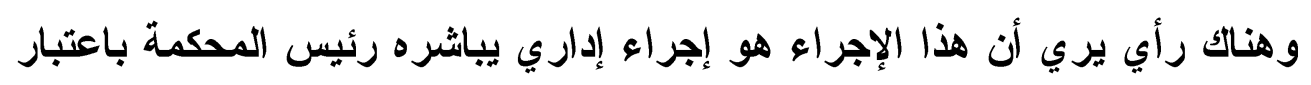

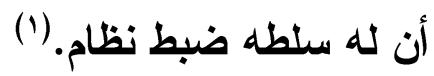

أما السلطة الثانية الواردة في نص المادة محل التعليق ، هي ســلطة لهيئـة

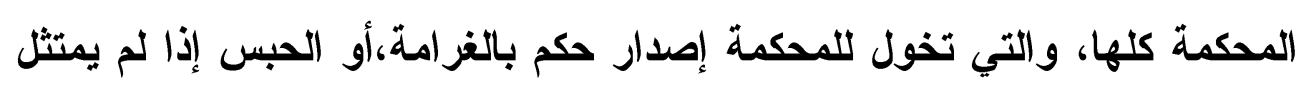

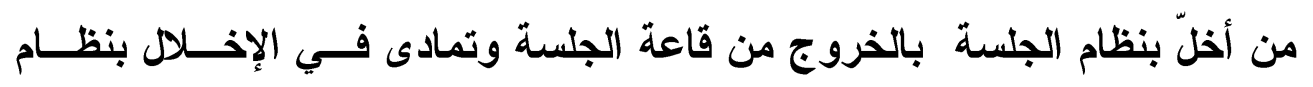

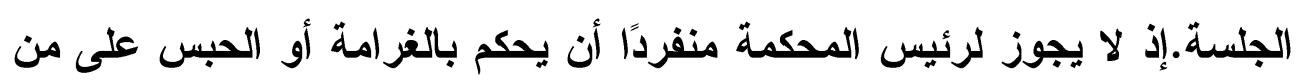

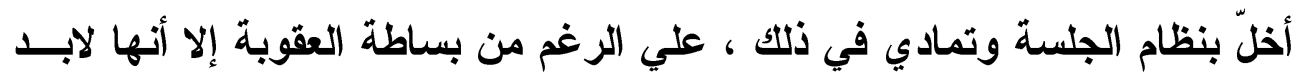

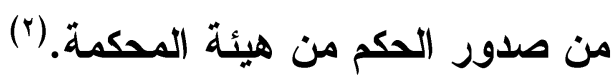

ثم جاء المشرع المصري، ونص صر هاحة على عدم جواز استئناف هذا الحكم

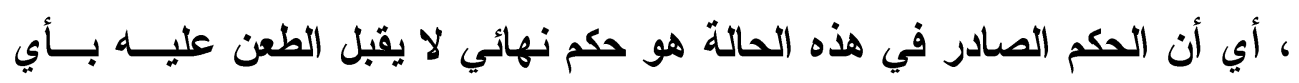

(1) آمال عثمان شرح قانون الإجراءات الجنائية ، الهيئة المصرية العامة للكتـاب، ط او 199، ص וr (ri

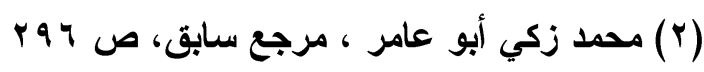


طريق من طرق الطعن العادية أو الغير العادية. فهو لا يقبل الطعـن بالاســتئناف

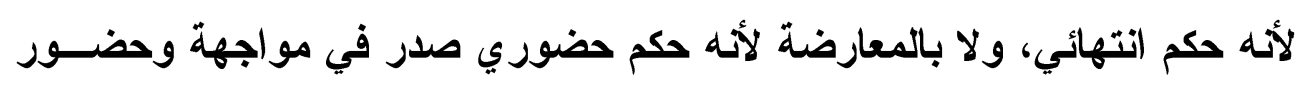
المتهم، ولا يقبل النقض لأنه صادر في مخالفة.

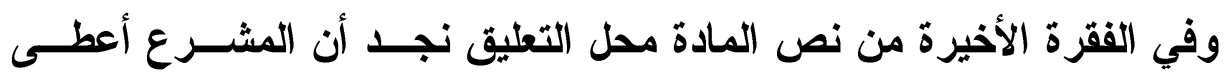

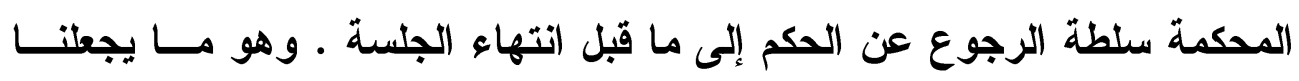
نتساعل عن طبيعة هذا الحكم.

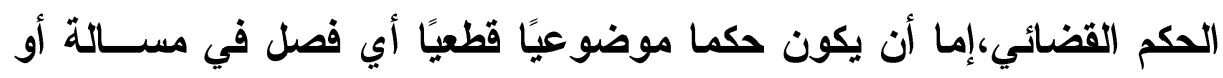

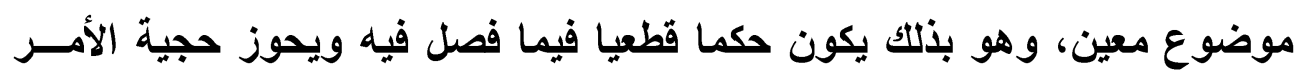

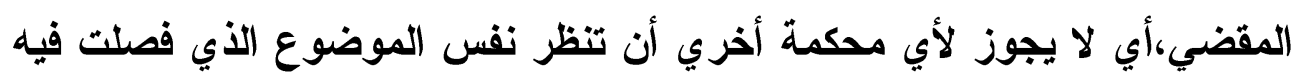

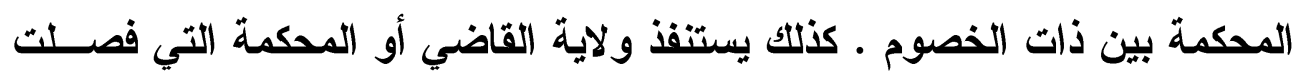

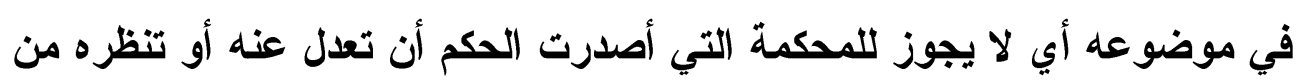

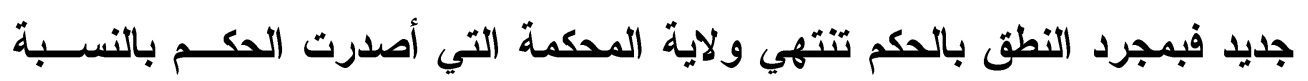

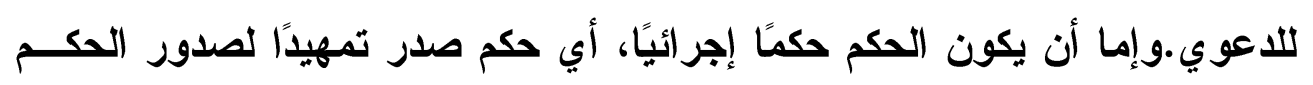

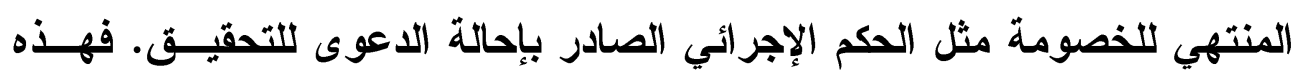

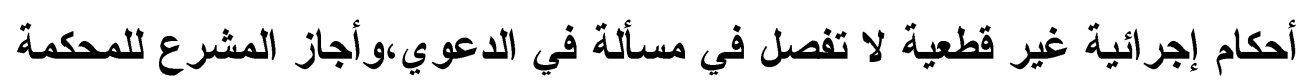

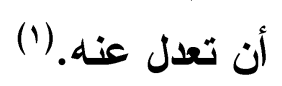

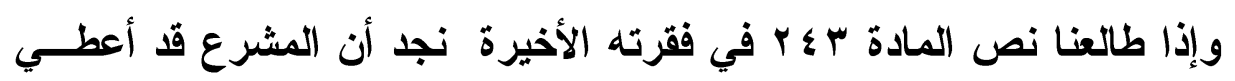

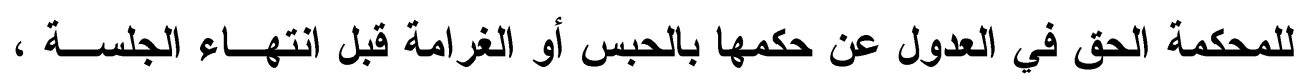

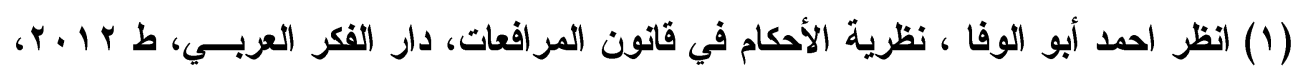
ص س זی 
على الرغم من أن الحكم بالحبس أو الغرامة هو حكـم موضــوعي قطعـي مـن المفترض أن له حجية ويستنفد ولاية المحكمة التي أصدرته.

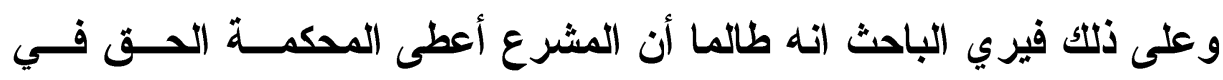
الرجوع عن الحكم فإننا لا نستطيع أن نقول عليه حكما بل هو قرار تنظيمي تملكه انده المحكمة لضبط نظام الجلسة وحفاظا علي هيبة ووقار المحكمة أمام المتقاضيين

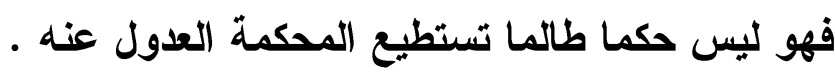

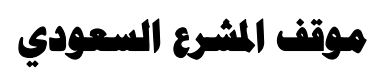

نصت المادة بـ ا من نظام الإجراءات الجزائية السعودي على أن " ضــبط

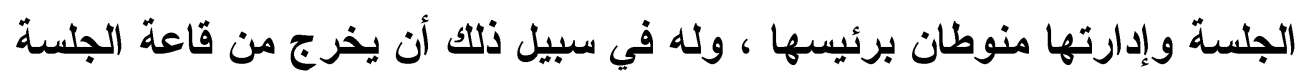

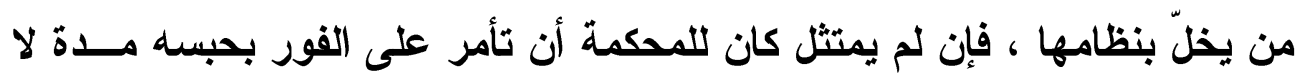

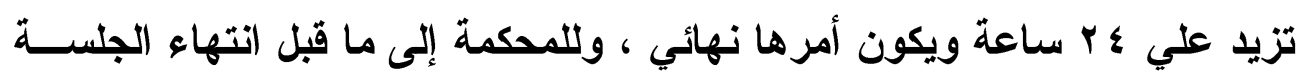
أن ترجع عن ذلك الأمر " تربل

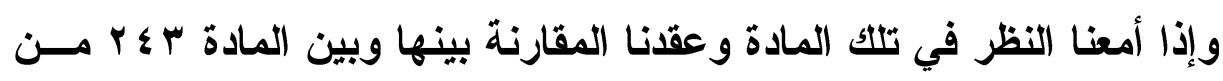
قانون الإجراعات الجنائية المصري سالف البيان نجدها متطابقة فـــي الســلطتين

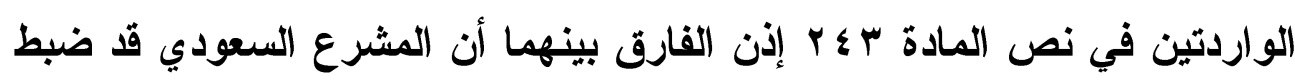

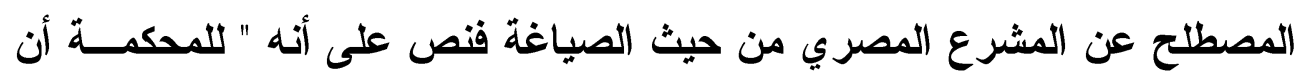

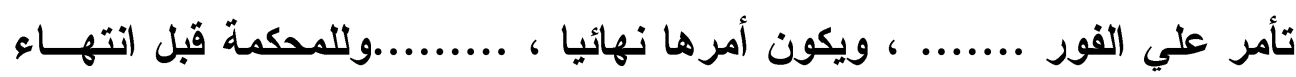
الجلسة أن ترجع عن ذلك الأمر

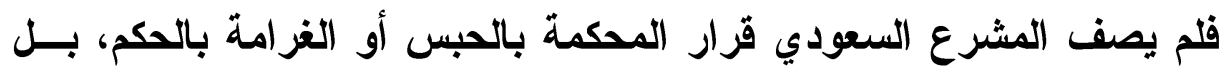

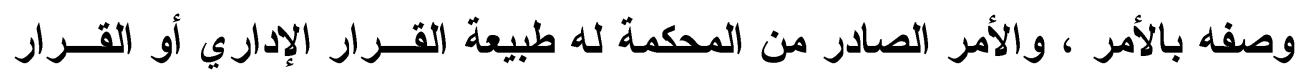

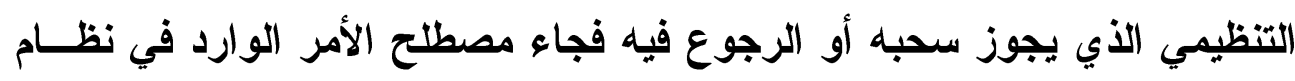


السعودي اقرب إلى الطبيعة الفعلية للإجراء والتي هي بعيدة تماما عن مصــلح (الحكم . (1)

\section{ثانيا: ارتكاب جناية أو جنحة أثناء الجلسة :-}

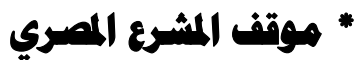

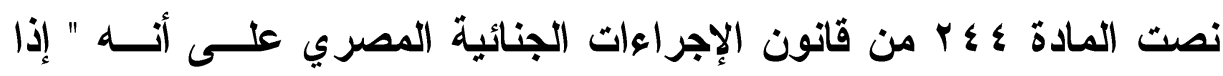

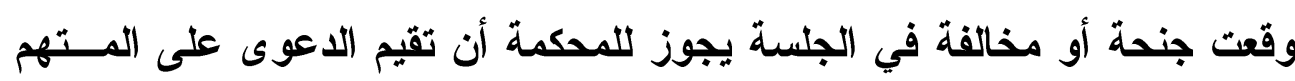

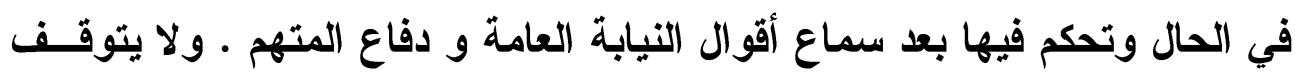
رفع الاعوى في هذه الحالة علي شكوى أو طلب إذا كانت الجريمة من الجــــائم

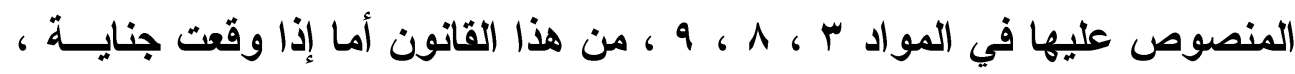

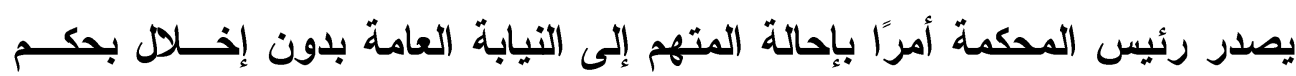

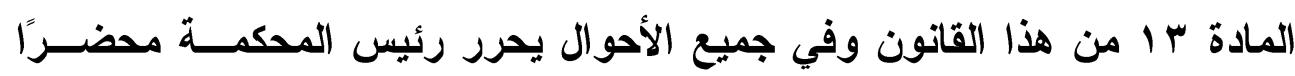

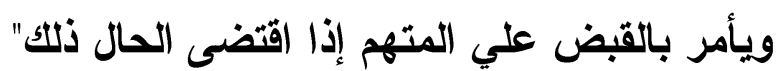

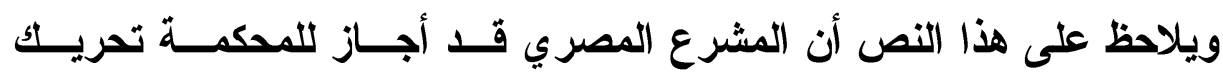
الدعوى الجنائية وإجراء تحقيق ومحاكمة المتهم وسوف نتعرض لذألك فيما يلي:

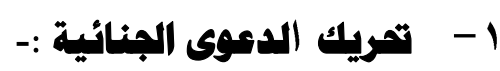

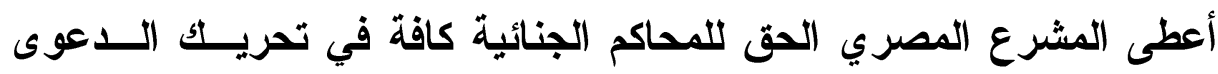

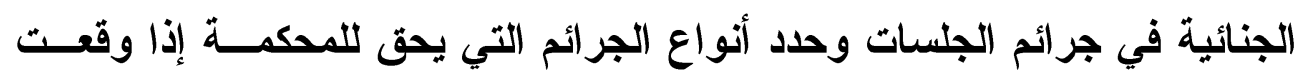

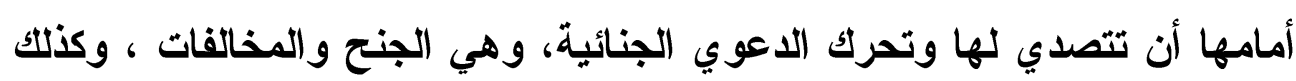

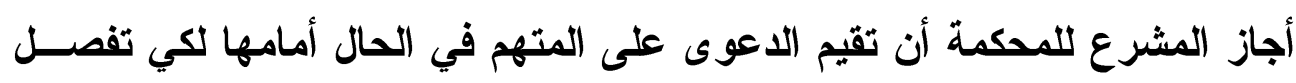

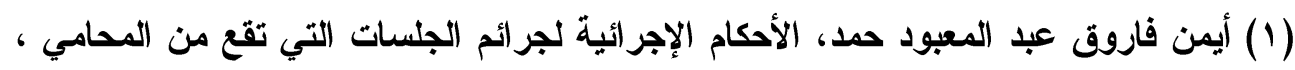

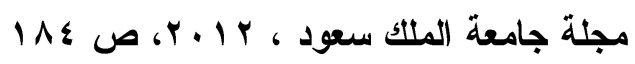


فيها بنفسها، ومناط ذلك أن تكون الجنحة أو المخالفة قد وقعت في الجلسة وقــــ

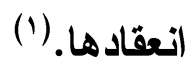

كذلك نجد الإثـارة إلى أن حق المحاكم في الحكم في جرائم الجلســات لــيس

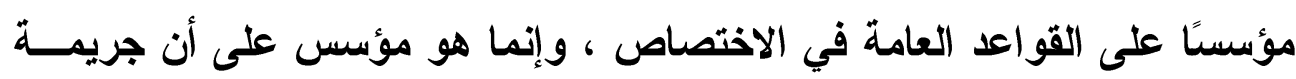

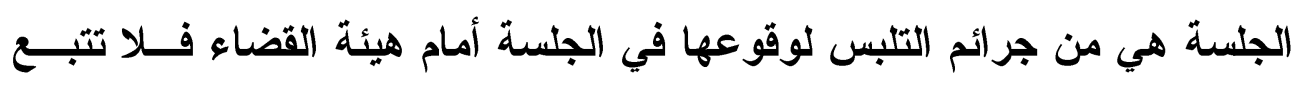

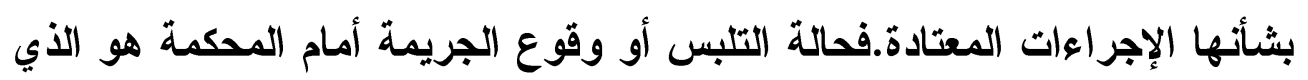

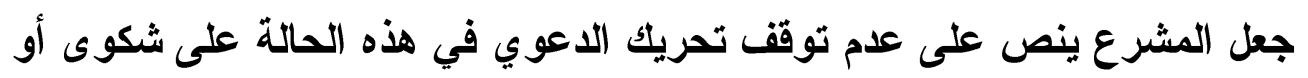

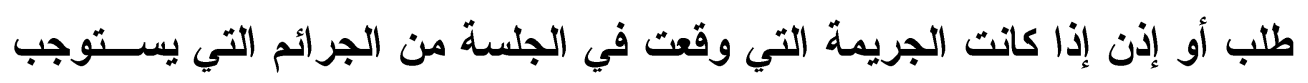

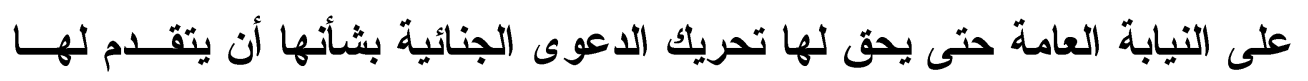

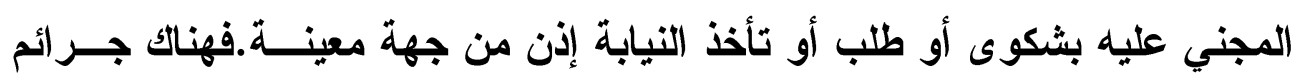

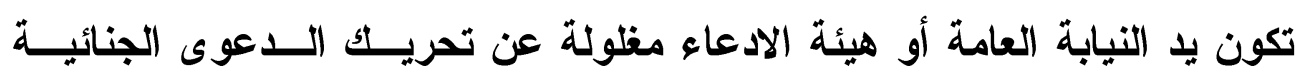

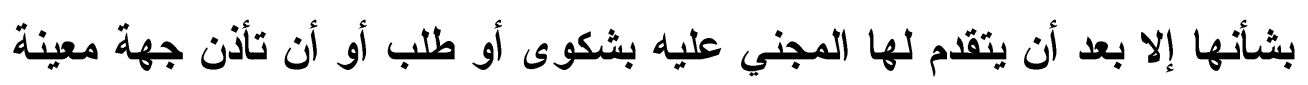

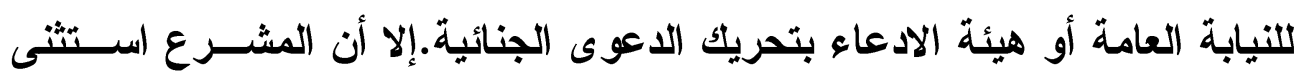

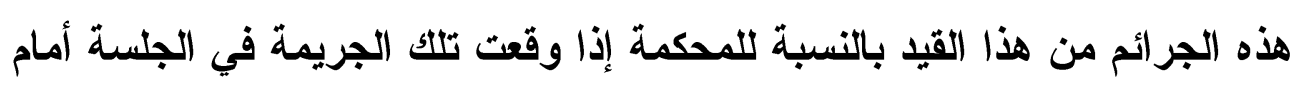

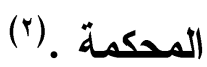

أما إذا كانت الجريمة التي وقعت أمام المحكمة في الجلسة جناية فقد خصها المشرع المصري بإجراء يختلف عن الجنحة والمخالفة.

(1) احمد فتحي سرور ، الوسيط في قانون الإجراعات الجنائية ، الكتاب الأول، الطبعة العاشرة NOr

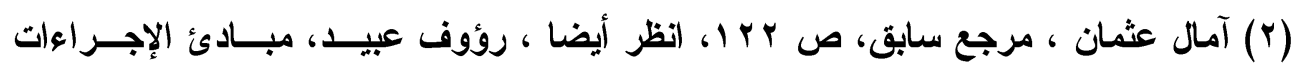

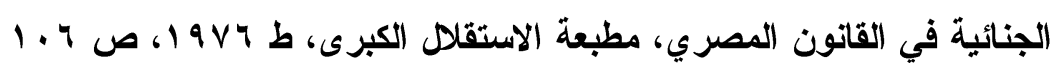


فنص المشرع المصري في حالة وقوع جناية أن يصدر أمسرا مسن رئسيس

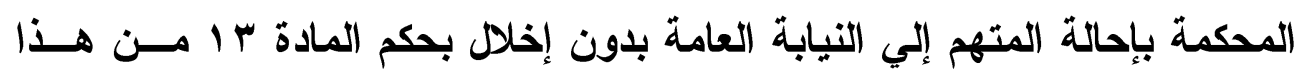

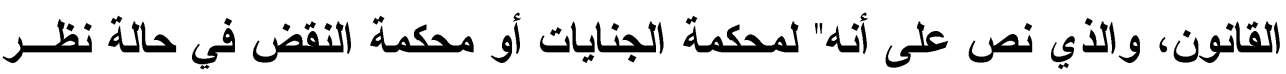

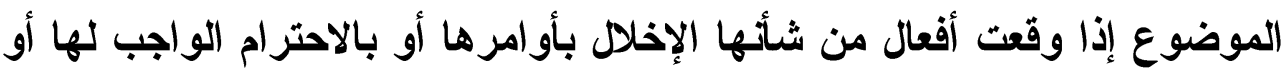

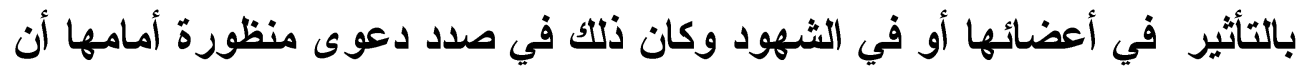

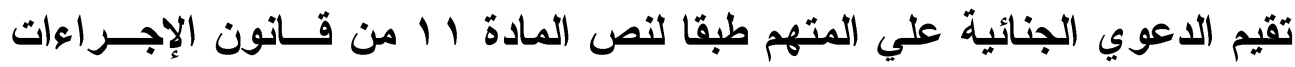
الجنائية المصري.(1)

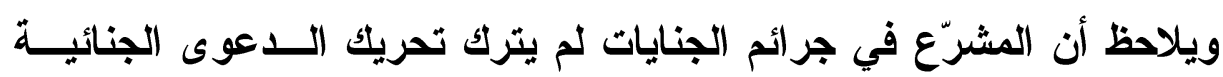

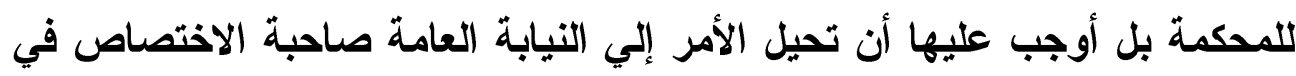

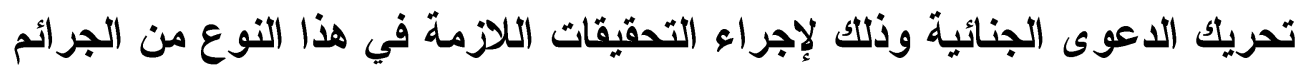
وغرض ذلك هو انه إذا كان المشرّع أعطى للمحكمة حق تحريك الاعوى الجنائية

(1) تنص المادة 11 من قانون الإجراءات الجنائية المصري على أنه " ذا رأت محكمة الجنايات

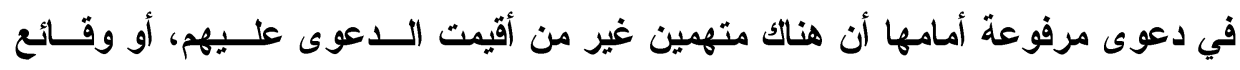

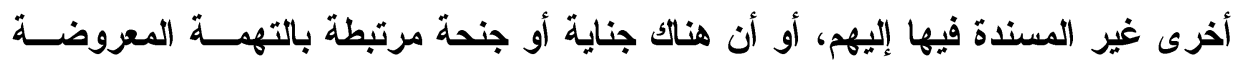

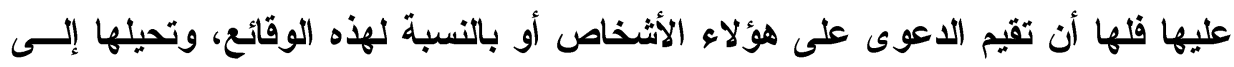

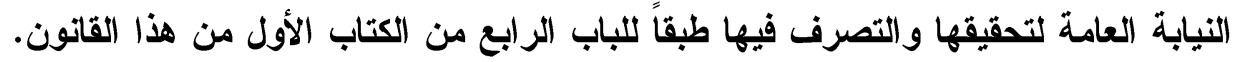

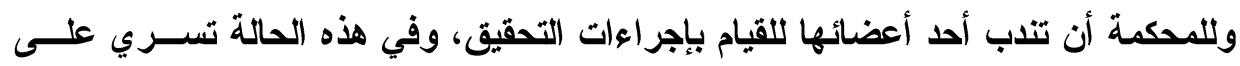

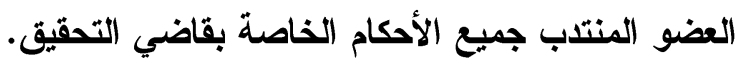

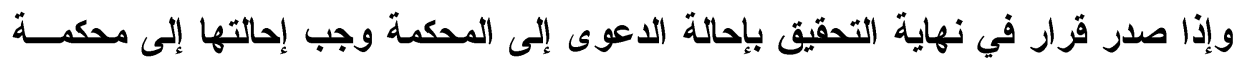

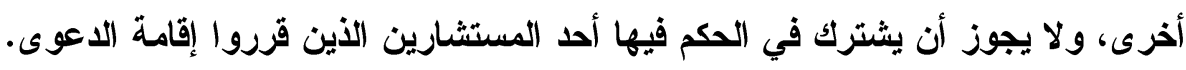

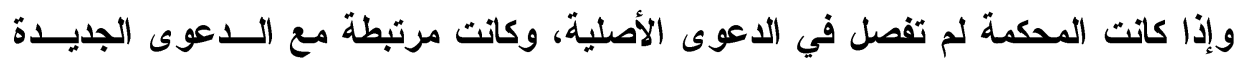
ارتباطاً لا يقبل التجزئة، وجب إحالة القضية كلها إلى محكمة أخرى. 


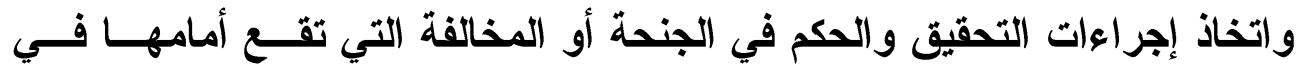

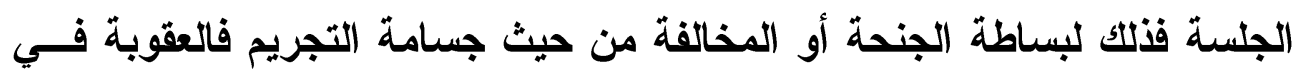

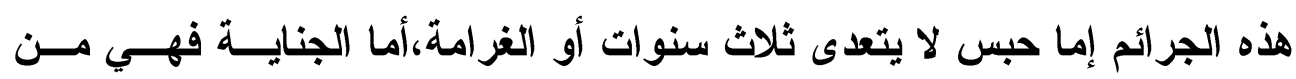

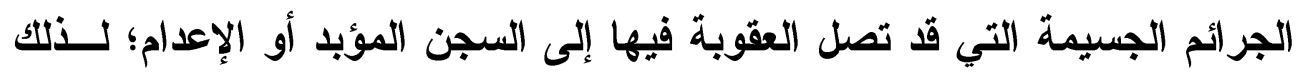

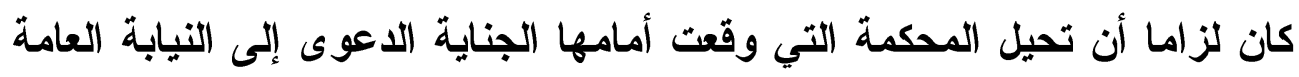
لتحقيقها واتخاذ ما تراه بشأنها.

$$
\text { r- التمقيق :- }
$$

\section{هوقف المشرع المصري}

أجاز المشرع المصري للمحكمة في حالة وقوع جريمة من جرائم الجلســات

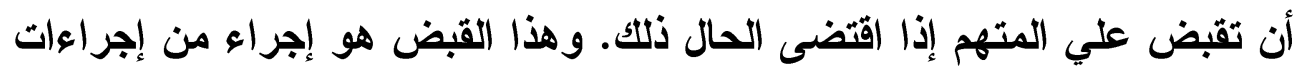

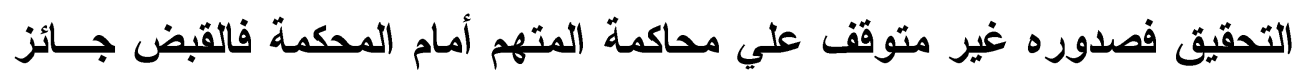

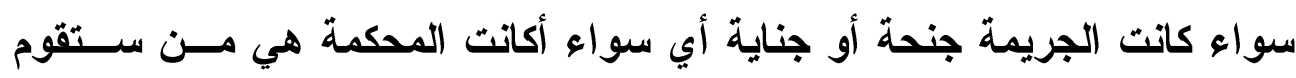

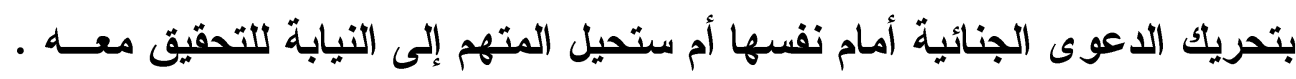

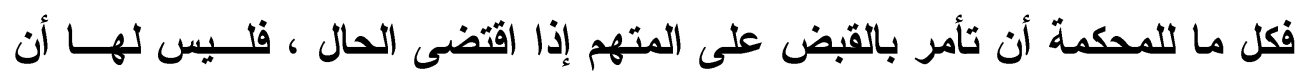

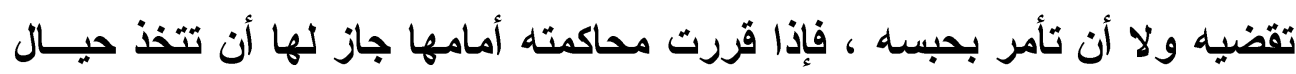

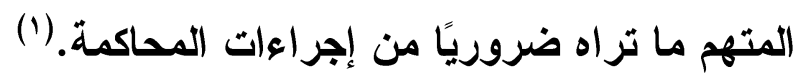

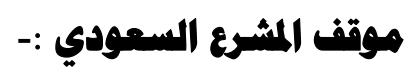

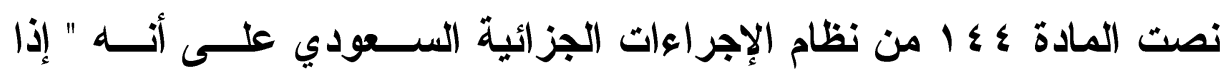

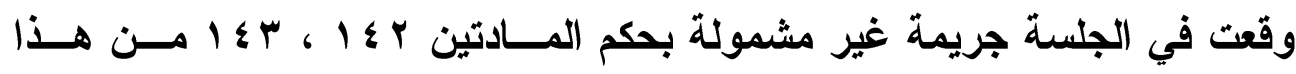

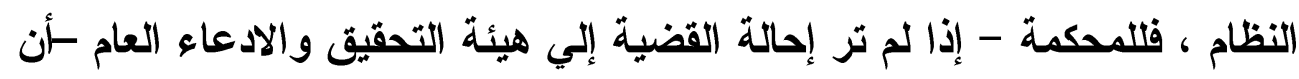

(1) احمد فتحي سرور ، المرجع السابق، ص 1001 
تحكم على من ارتكبها وفقًا للمقتضي الثرعي بعد سماع أقوالــهـه ، إلا إذا كــان

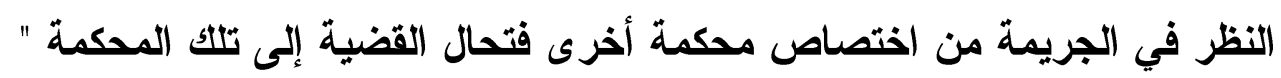

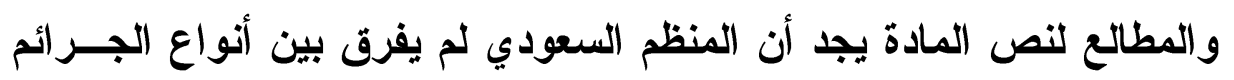

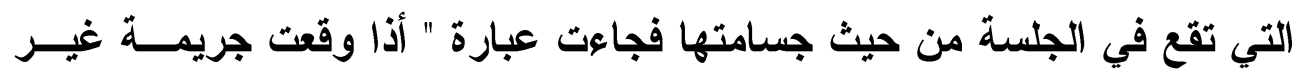

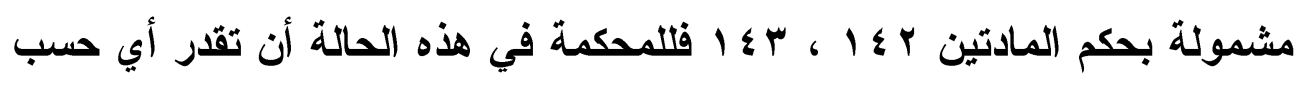

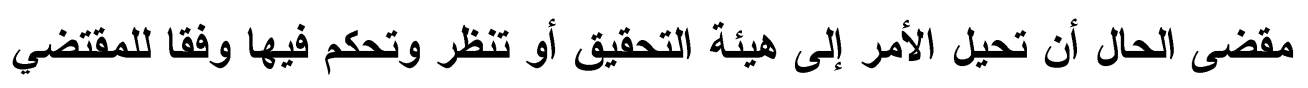

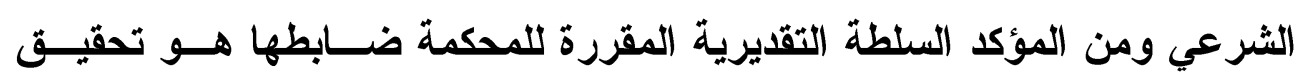
العدالة وإظهار الحقيقة ـ فقد ترى المحكمة أن الجريمة التي وقعت أمامها تحتّاج

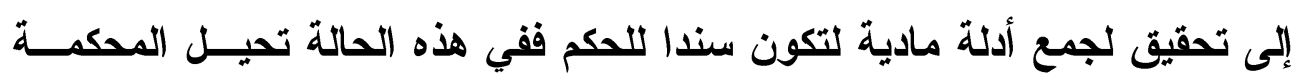

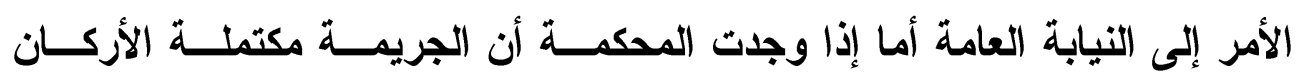
وتستطيع أن تفصل فيها فورا ففي هذه الحالة تتصدى المحكمة لتبلك الجريمة .

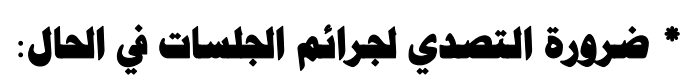

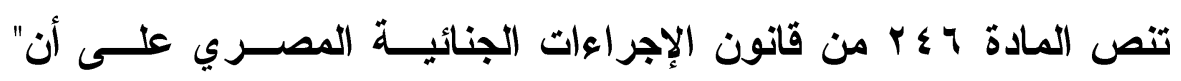

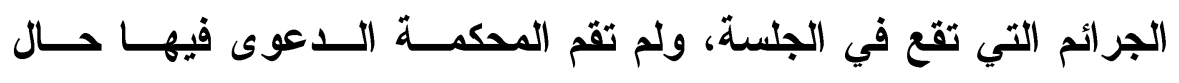
انعقادها، يكون نظر ها وفقاً للقو اعد العادية".

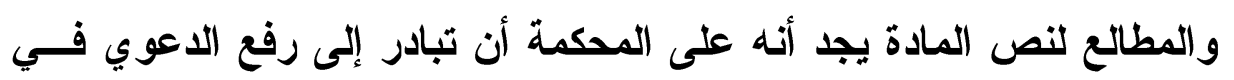

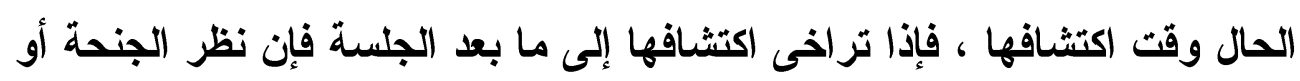

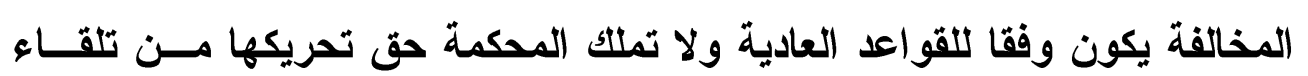

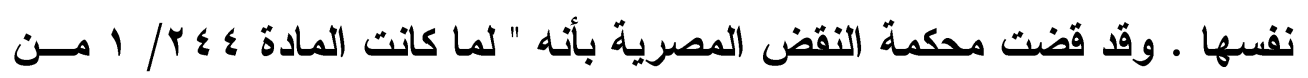

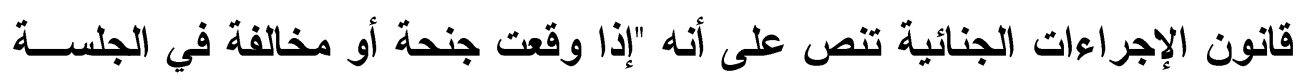

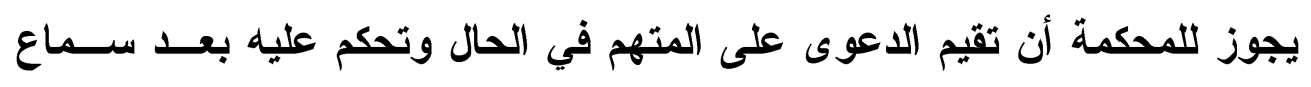




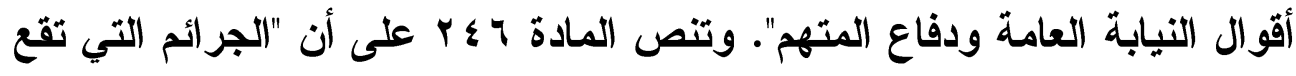

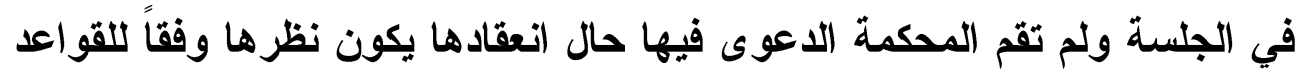

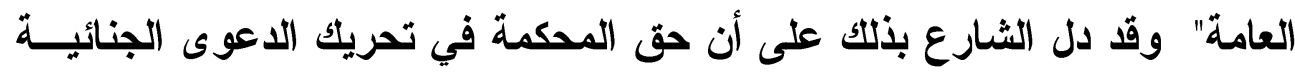

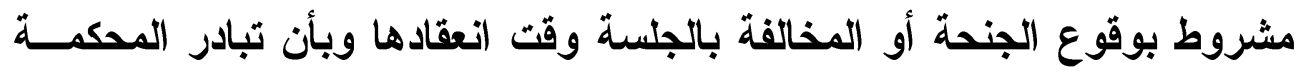

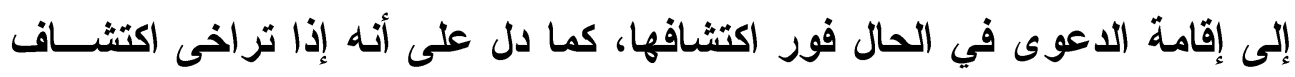

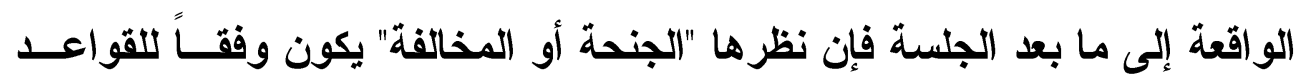

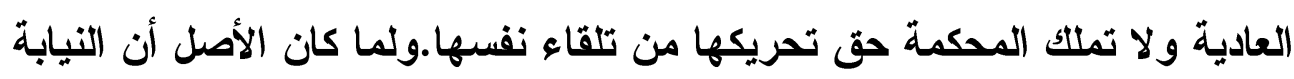

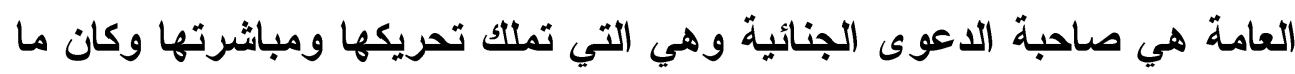

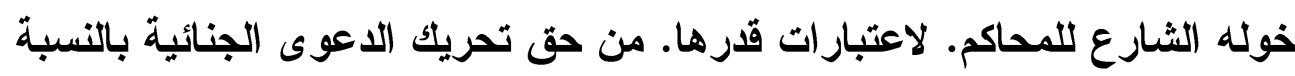

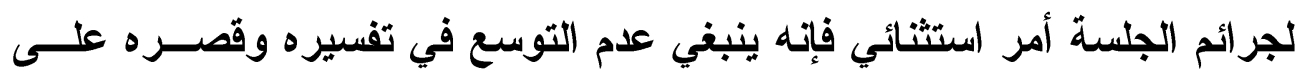
أضيق نطاق. (')

وكذلك قضت محكمة النقض المصرية بأنه " ينتهي انعقاد الجلســة المحــددة

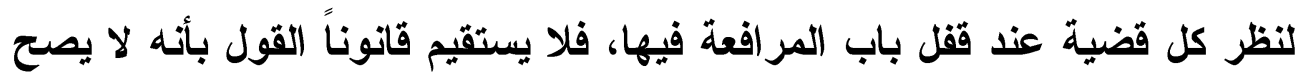

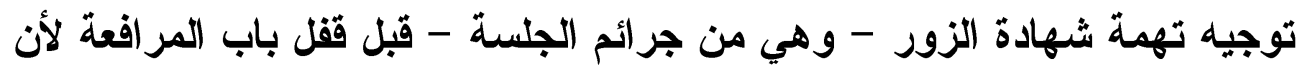

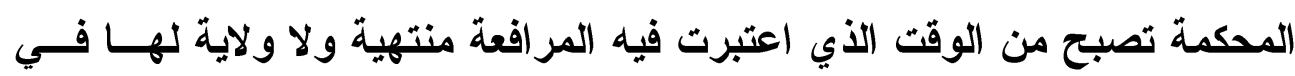

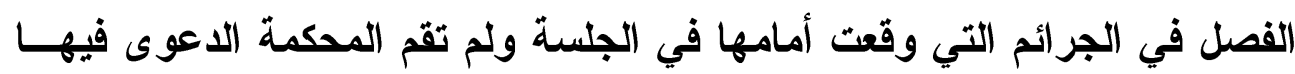

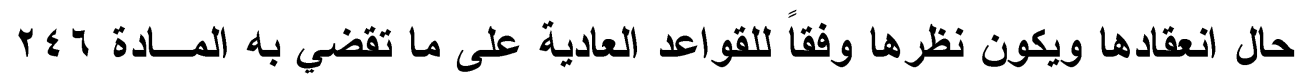

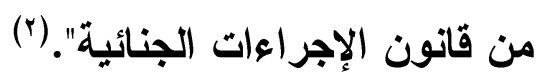

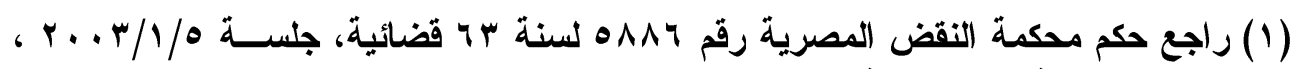

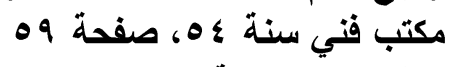

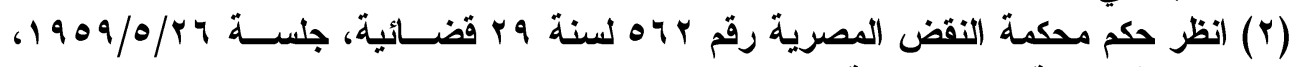

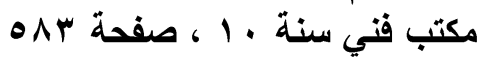




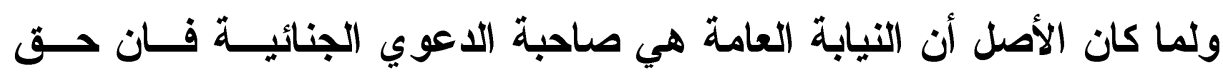

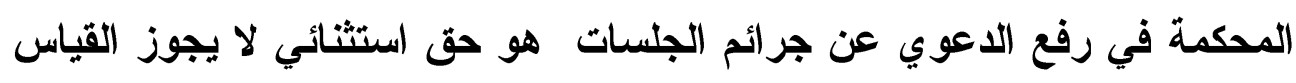

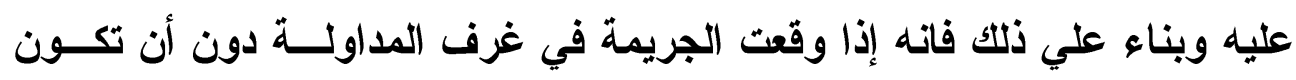

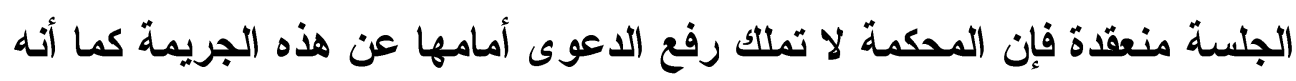

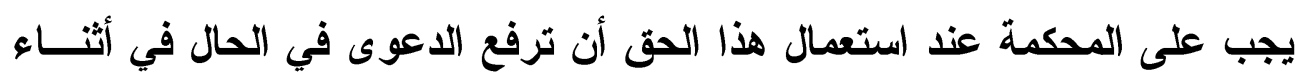

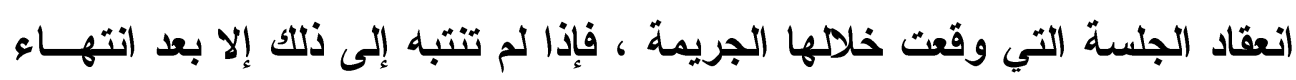
الجلسة فإنها لا تكون مختصة بتحريك الاعوى الجنائية. (1)

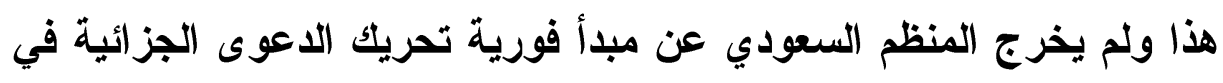

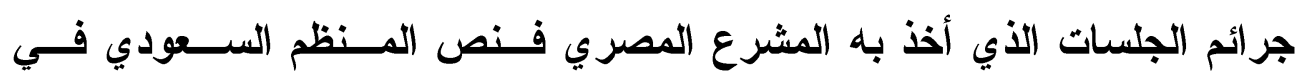

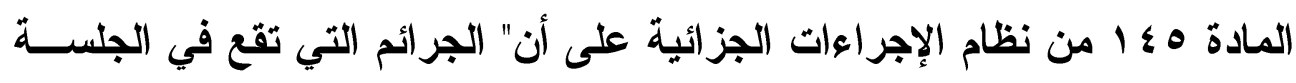

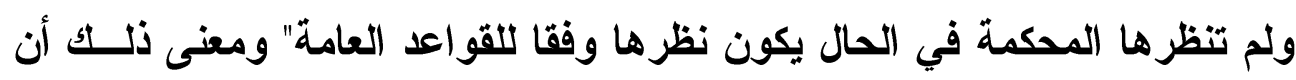

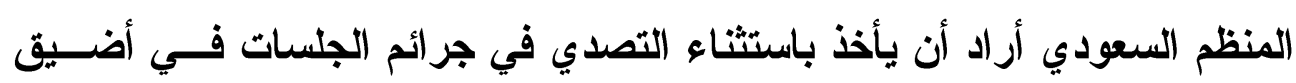

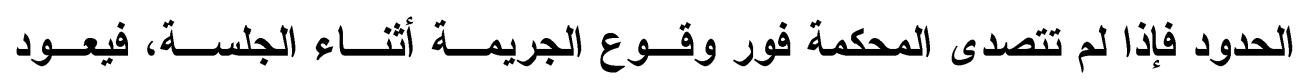
الاختصاص بتحريك الاعوى الجزائية في يد سلطة التحقيق والاتهام.

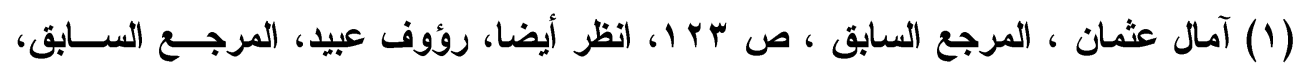

$$
\text { ص V. آمان }
$$




\section{الإلب الثاني \\ وقوع جرائم البلسات من الماهيين}

نصت المادة 0 \& من قانون الإجراءات الجنائية المصري على أنه "استثناء من الأحكام المنصوص عليها في المادتين السابقتين إذا وقع من المحامي أثنــاء

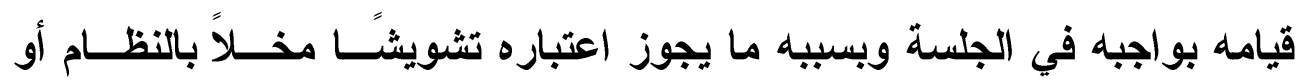
ما يستدعي مؤاخذته جنائيًا يحرر رئيس الجلسة محضر ا بما حدث . وللمحكمة أن تقرر إحالة المحامي إلى النيابة العامة لإجراء التحقيق إذا كان ما وقع منه ما يستدعي مؤاخذته جنائيا، وإلى رئيس المحكمة إذا كان ما وقع منه يستدعي مؤاخذته تأديبيًا وفي الحالتين لا يجوز أن يكون رئيس الجلسة التي وقع

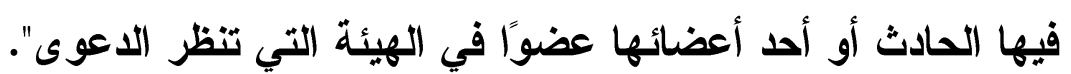

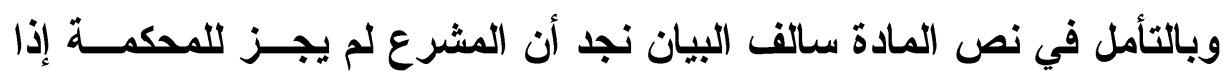
وقعت من أحد المحامين جريمة في الجلسة أن تقبض عليه وأن تحاكمه أمامها ، وكل مالها هو أن تأمر بتحريك الاعوى الجنائية قبله عن طريــق الإحالــة إلـى

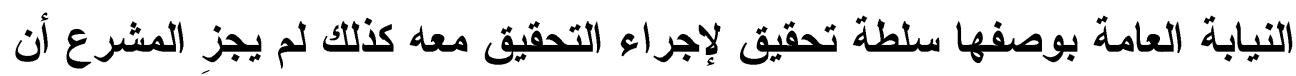
يكون رئيس الجلسة التي وقعت فيها الحادث أو أحد أعضائها عضوا في الهيئسة

التي تنظر الاعوي . (1)

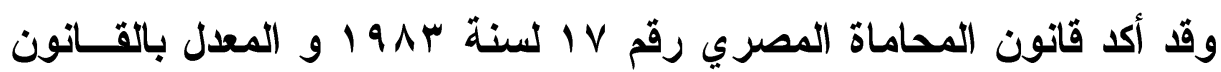

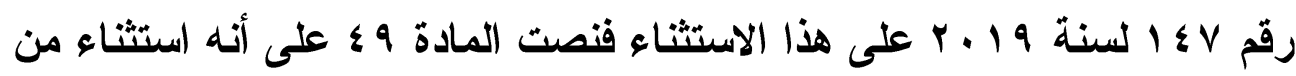

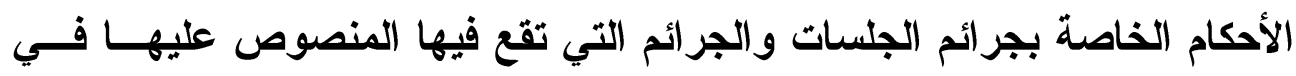

(1) احمد فتحي سرور، مرجع سابق، ص 
قانوني المرافعات والإجراءات الجنائية - إذا وقع من المحسـامي إثنــاء وجـوده بالجلسة لأداء واجبه أو بسببه إخلال بنظام الجلسة أو أي أمر يستدعي محاسبته

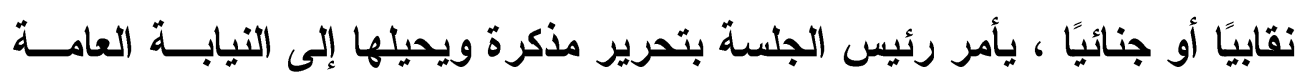

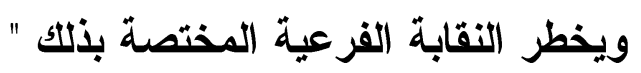

وأراد المشرع المصري من وراء هذا الاستثناء أن يضــمن للمحسامي أداء

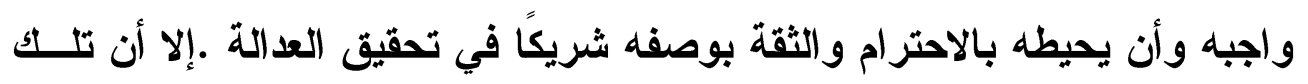

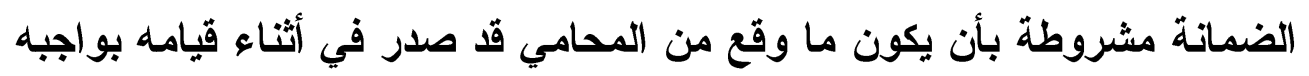

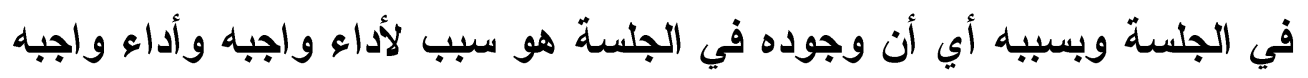

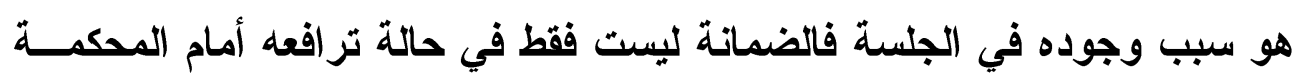

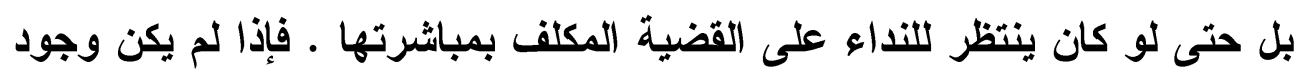

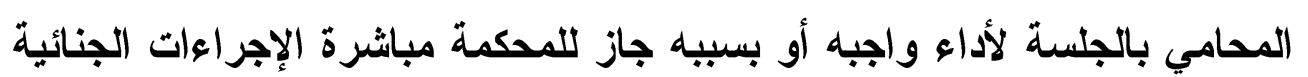

ضده. (1)

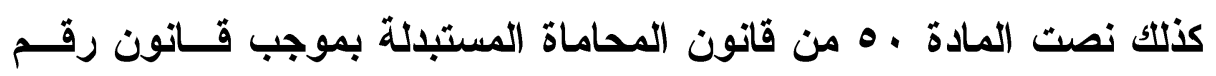

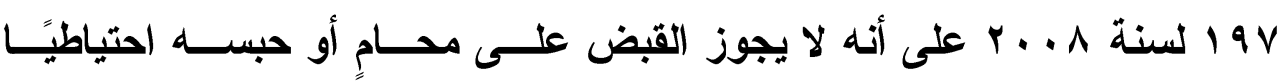

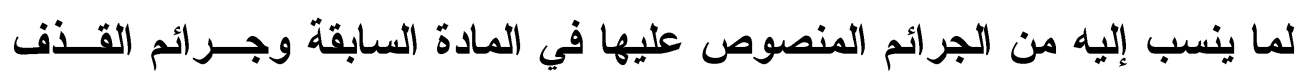
و السب و الإهانه بسبب أقو ال أو كتابات صدرث منه في إثناء أو بسبب ممارسته

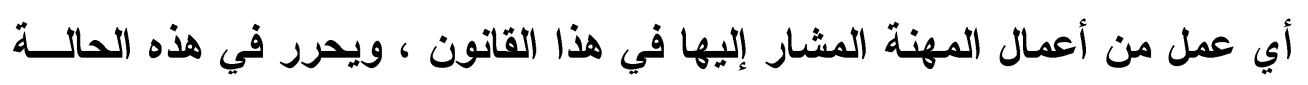

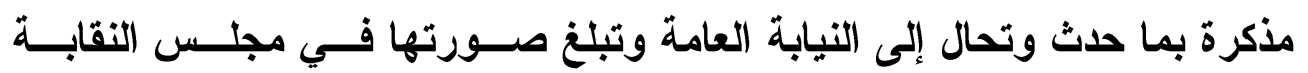

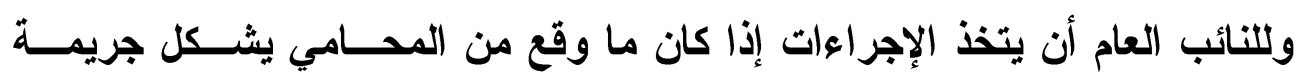

(1) احد فتحي سرور ، مرجع سابق ، ص 104 ، انظر أيضا ، محمد زكي أبو عامر ، مرجع

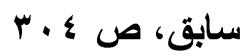


معاقب عليها في قانون العقوبات ، أو أن يحيله إلى مجلس النقابة إذا كان ما وقع

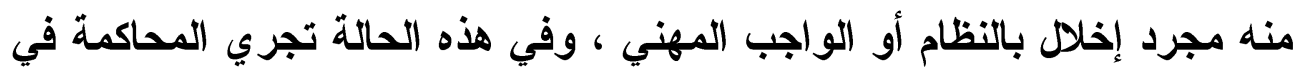

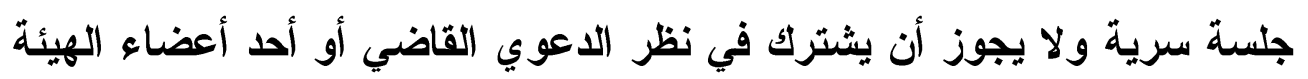

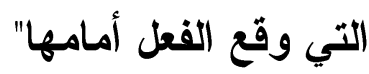
وهكذا وجلنا أن المشرع المصري قد استثنى المحامين من أحكــام جـرائم الجلسات وخصهم بإحكام تناسب الدور الذي يقوم به المحامي حتى يقوم بما تمليه

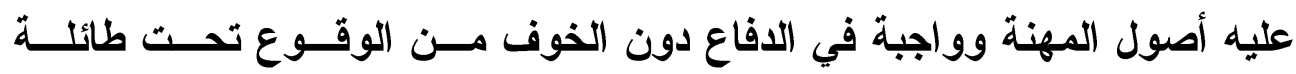
المساءلة القانونية . وبمطالعة قانون الإجراعات الجزائية السعودي لم يجد الباحث نــص مماثـل

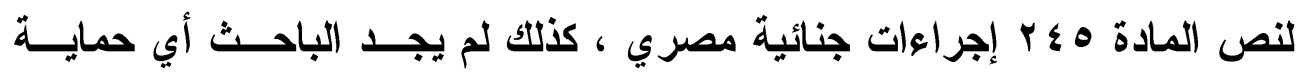

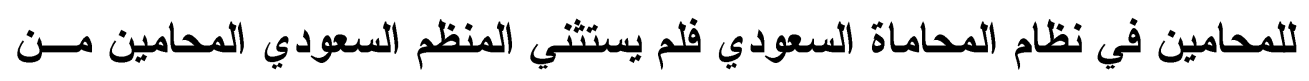

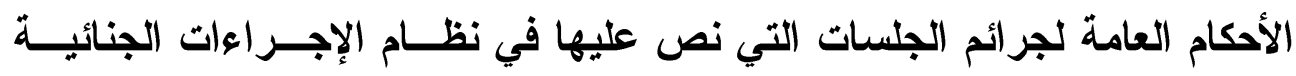

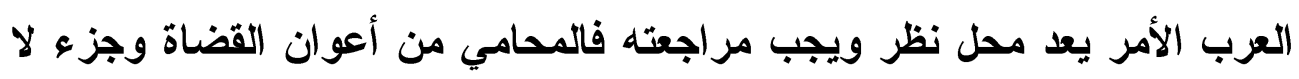

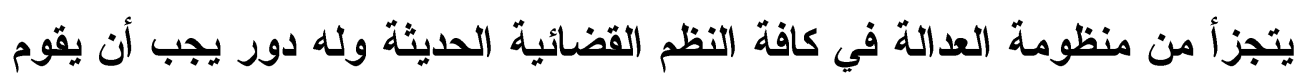

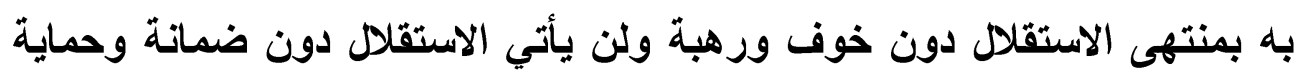

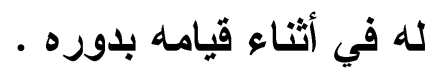




\section{المبمث الثاني \\ أمكام جرانم الجمسات أمام القاضي المدني}

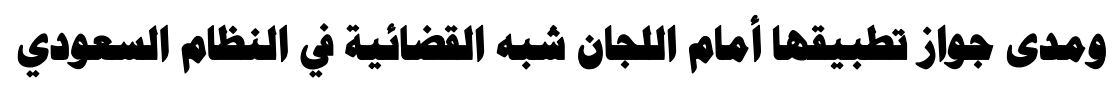

رأينا في المبحث السابق أن المشرع - المصري والسعودي - قــــ أعطـى

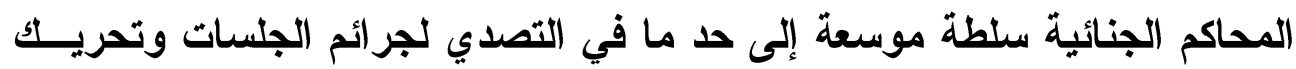
الاعوى الجنائية بشأنها وإن كان ذلك منطقيًا حيث أن نظر الجرائم و الحكم فيهــا هو من اختصاص المحاكم الجنائية، ولكن هل أعطى المشرع المصري والسعودي ذات السلطة - التي منحها للمحاكم الجنائية - إلى المحاكم المدنية و اللجان شــبه القضائية في حالة وقوع جريمة من جرائم الجلسات. هذا ما سوف نبينه في هذا المبحث من خلال المطلب الأول الأي يكون حديثنا فيه عن جرائم الجلسات أمسام القضاء المدني ،أما المطلب الثاني فينصب فيه الحديث على جرائم الجلسات أمسـام الاجان شبه القضائية. 


\section{المالب الأول}

\section{جرانم البانسات أهام القضاء المدني \\ في القانون المصري و النظام السعودي المناي}

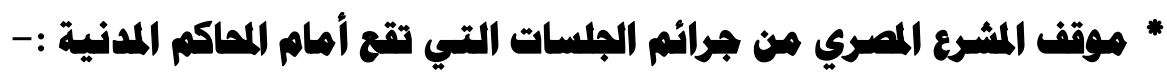

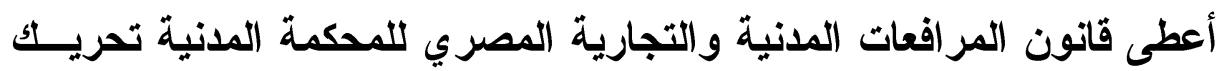

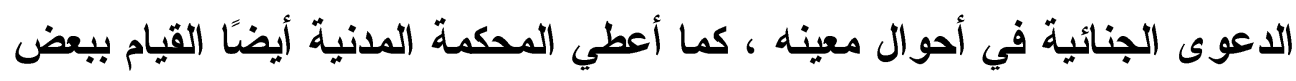

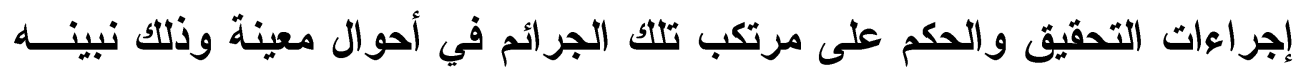
على النحو التالي :-

أولا : حق المحكمة المدنية والتجارية في تحريك الاعوى الجنائيــة واتخــاذ

$$
\text { إجراءات التحقيق. }
$$

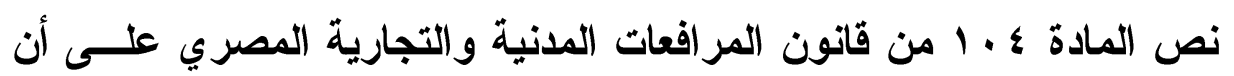

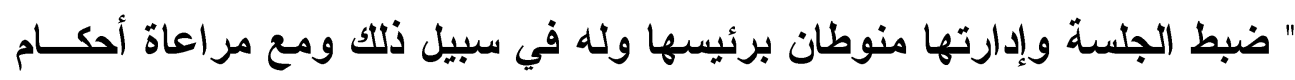

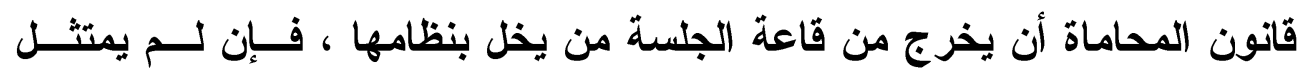

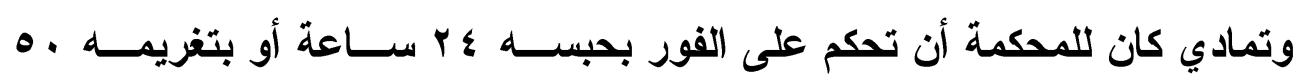

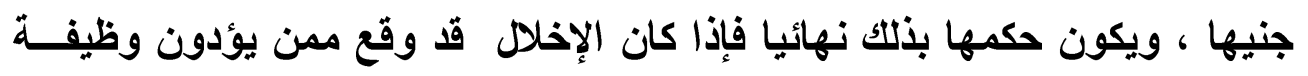

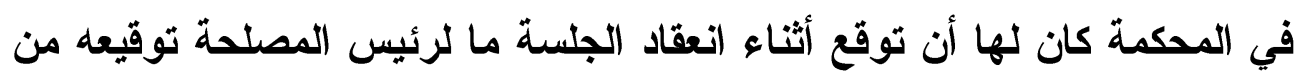

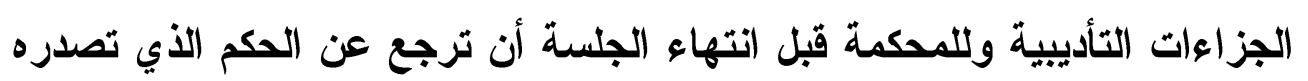
بناء على الفقرتين السابقتين"

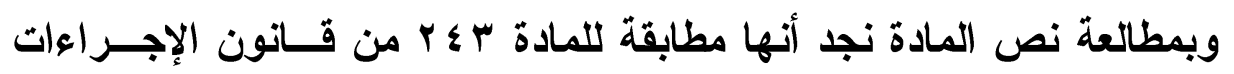
الجنائية والتي سبق لنا التعليق عليها ، وعليه فيرى الباحث منعاً للتكرار أن نحيل التيل إلى ما سبق ذكره . 


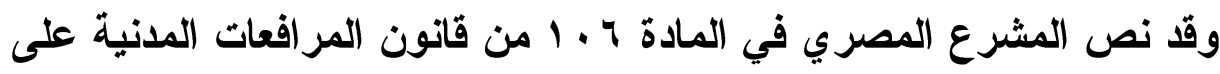

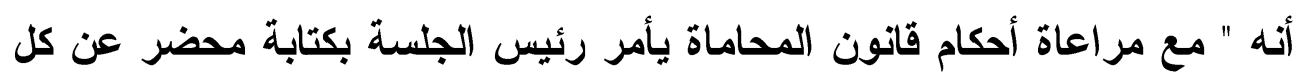

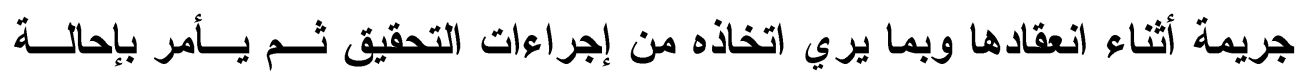

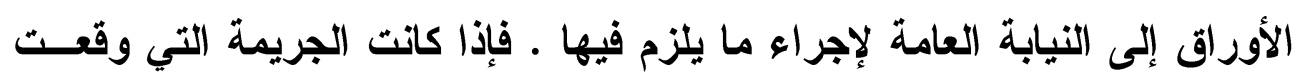

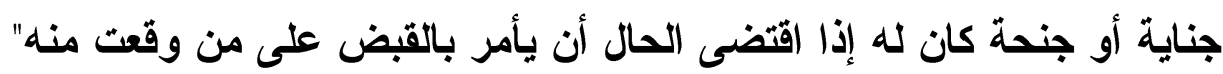

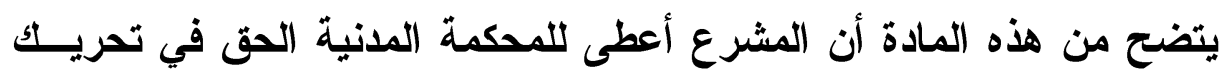
الاعوى الجنائية واتخاذ إجراعا من إجراعات التحقيق وهي القبض على المتهم إذا إنا

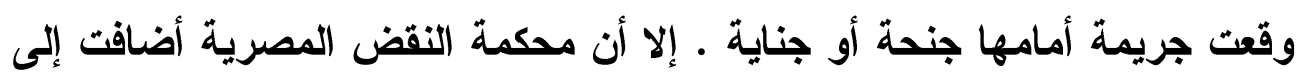

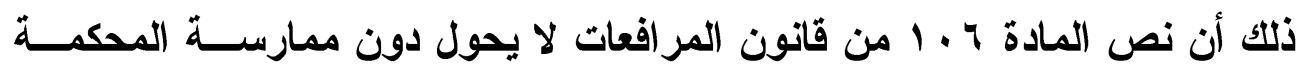

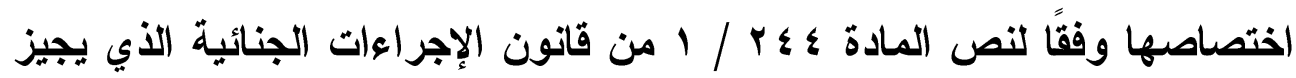

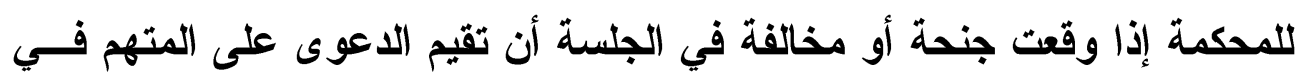

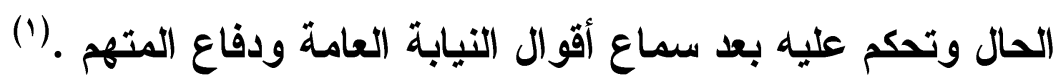

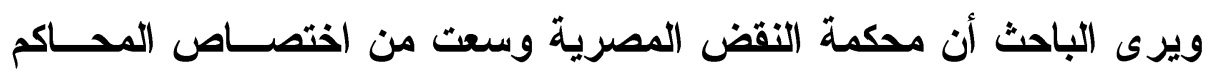

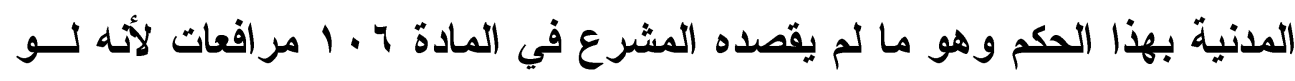

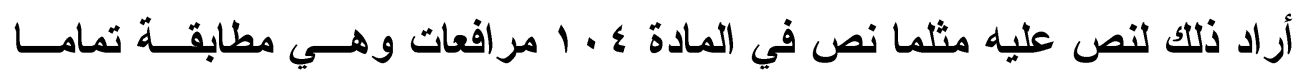

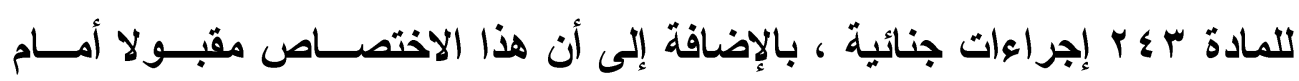

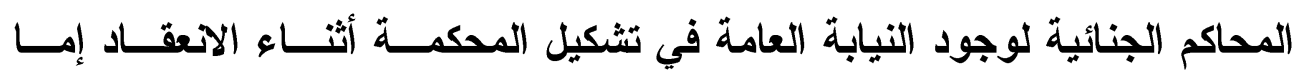

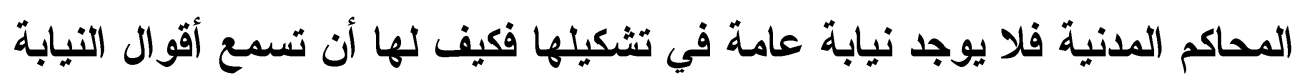

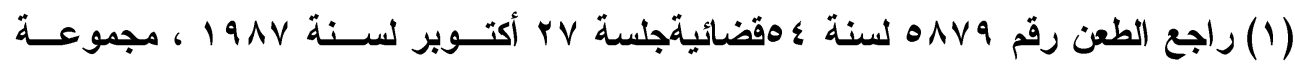

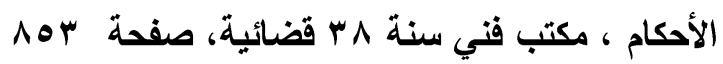


العامة ، فمقتضى العال يجب الإحالة للنيابة العامة للتصرف في الواقعـة التــي

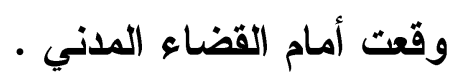

ثانيا: حق المحاكم المدنية في تحريك الدعوى الجنائية والحكم فيها :-

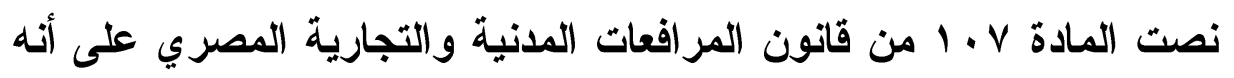

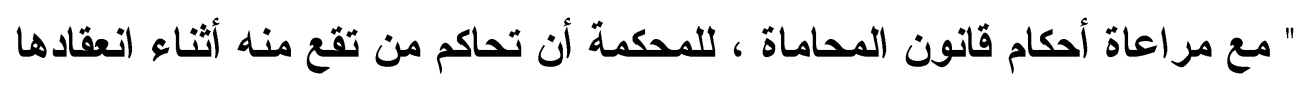

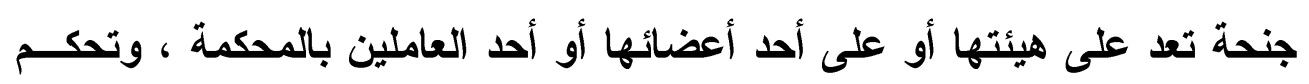

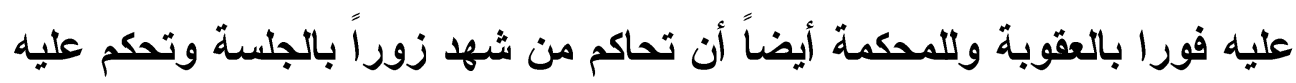

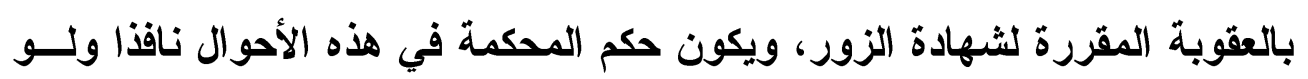
حصل استئنافه "

نجد في هذه المادة حالات محددة علي سبيل الحصر تجمع فيهــا المحكمـة

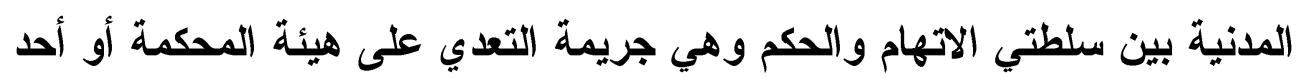

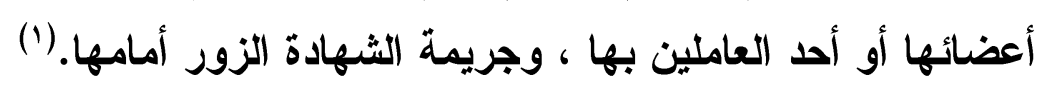

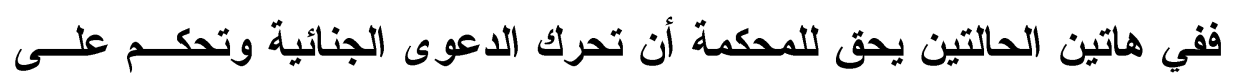

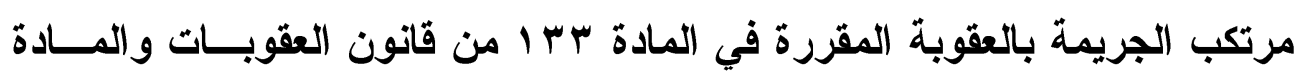

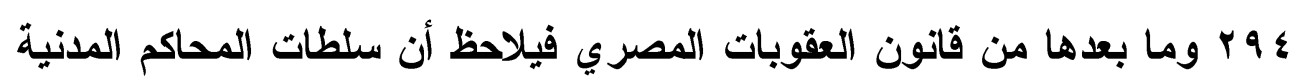

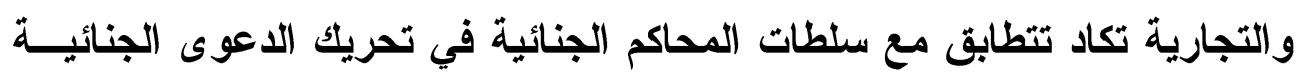

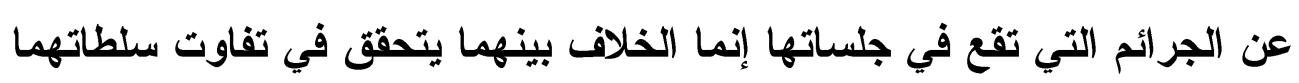

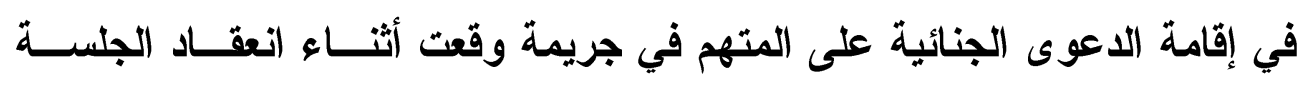

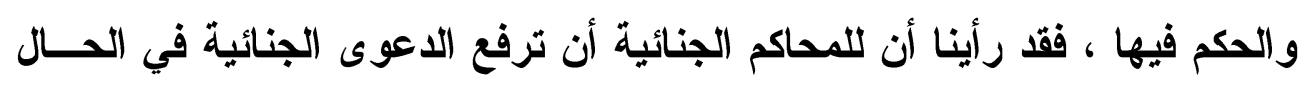

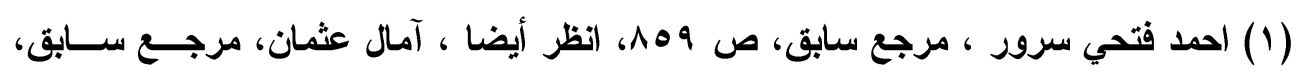

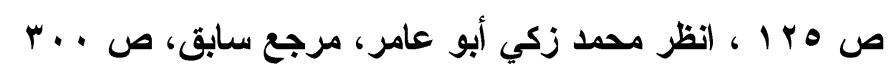




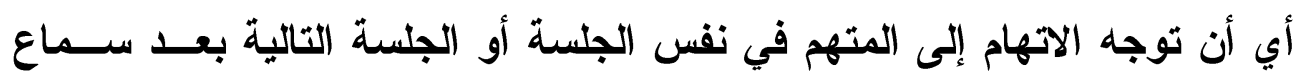

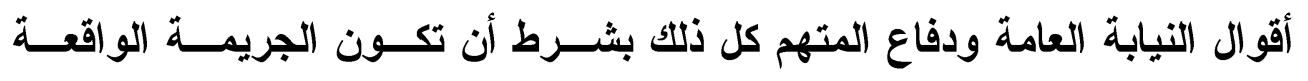

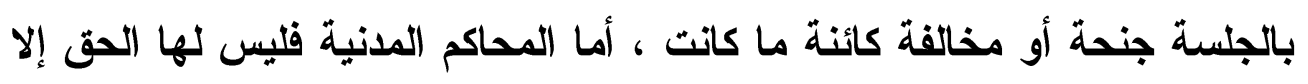

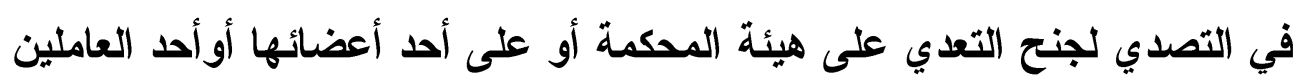

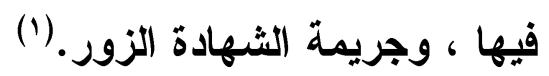
ومعنى هذا أن حق المحاكم الجنائية أو المحاكم الأخرى واحد فللمحاكم جميعًا

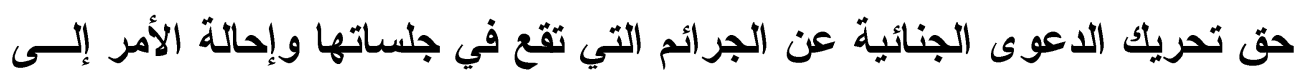

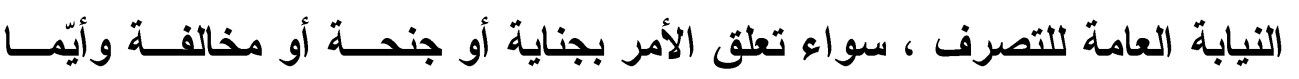

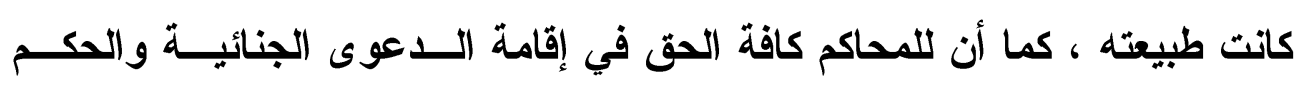
فيها نواته

نهاية الأمر أن هذا الحق مطلق في مواد الجنح والمخالفات للمحاكم الجنائية

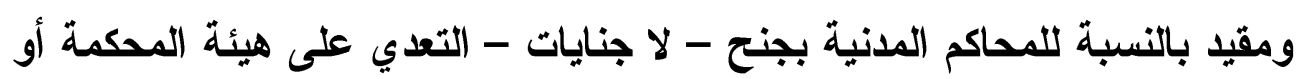

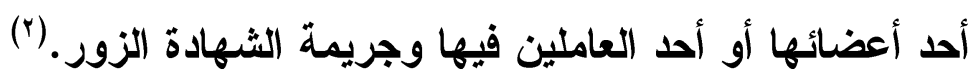

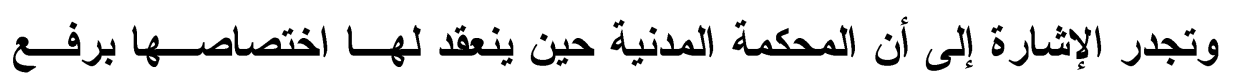

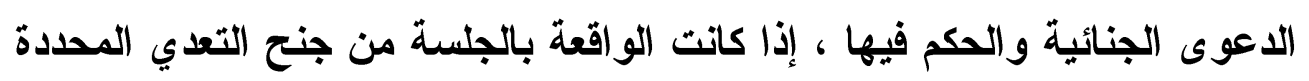

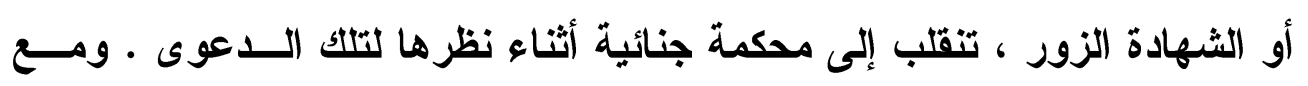

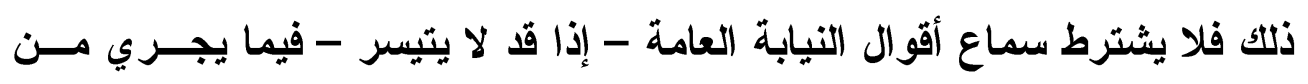

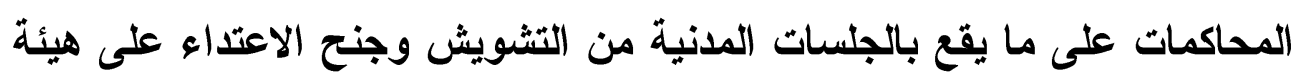

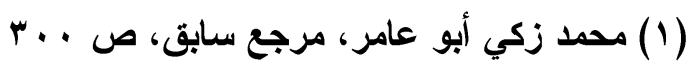

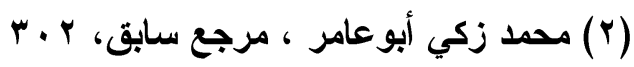


المحكمة أو على أحد أعضائها، على عكس ما يجري في تلك المحاكمـات أمسام

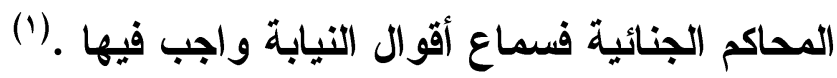

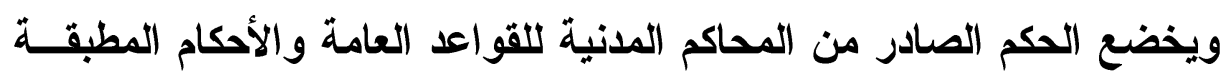
على الأحكام الجنائية من حيث طرق وإجراءات الطنادر هن الطن عليها ويكون الحكم الجنائي

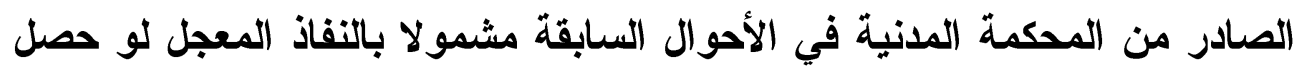

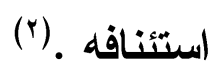

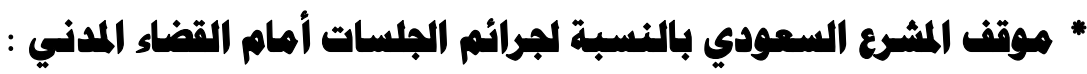

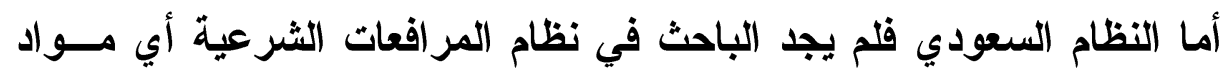

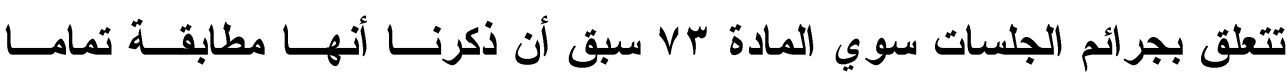

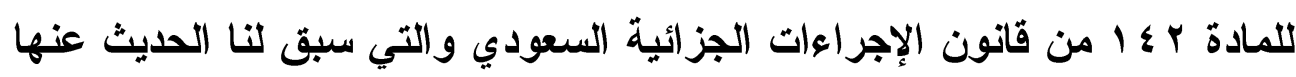

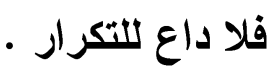

وهنا نلاحظ أن المنظم العسودي أعطى للمحكمة المدنية فقط الحق في تحريك

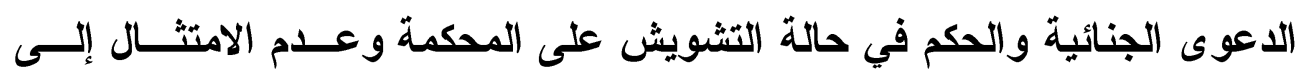

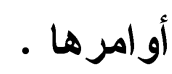

أما إذا وقع التعدي على هيئة المحكمة أو أحد أعضائها أو العاملين بها أثناء

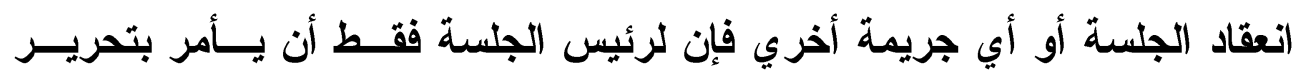

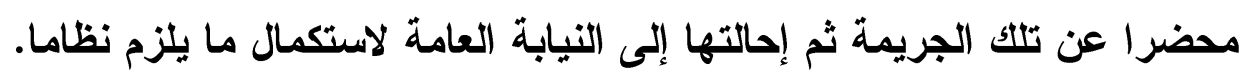

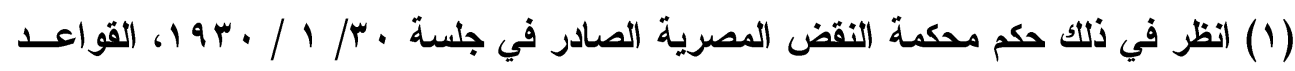

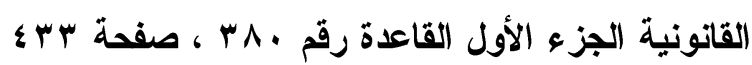

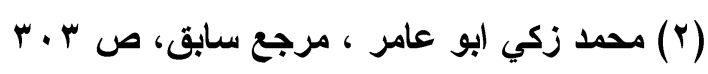


ويرى الباحث أنه يوجد قصور في سلطة المحاكم المدنية في حالــة التعـدي على هيئتها أو على أحد أعضائها، إذ لم يمنحها سلطة فئه تحريك الداعوى الجزائية في

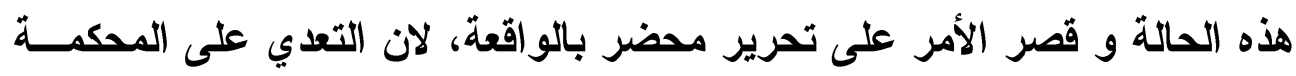

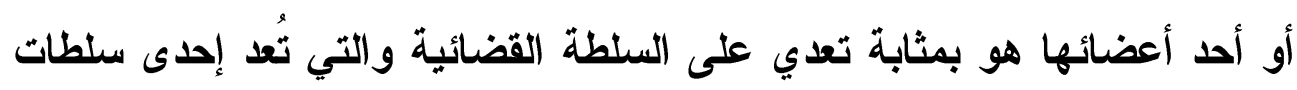
الدولة حفظاً لهيبة القضاء ولا فرق في هذه الحالة بين محاكم جنائية و محسـاكم مدنية. فمثلما أعطى الحقى في تحريك الدعوى الجزائية للمحاكم الجزائية في هذه فئه

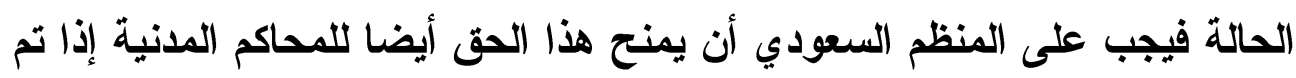

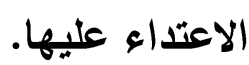

\section{الإطب الثاني \\ مدي تطبيق قواعد أمكام جرانم البلماتئ

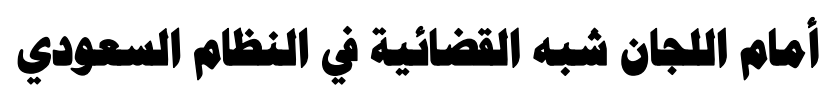

ونظراً لتنظيم السلطة القضائية وطبيعتها في المملكة العربية السعودية عمدنا

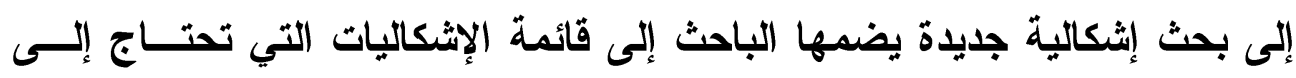

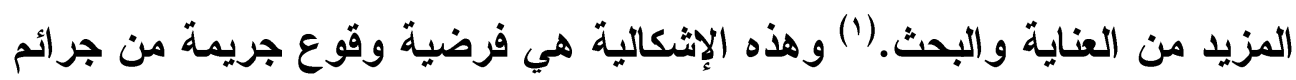

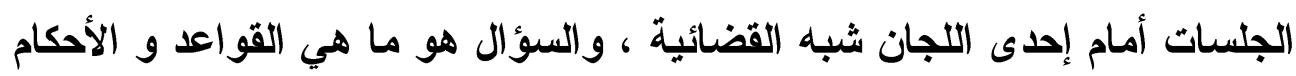

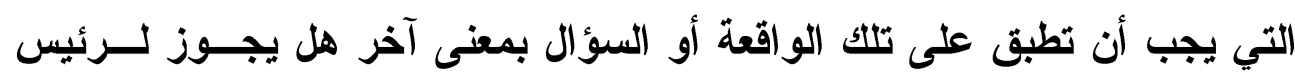

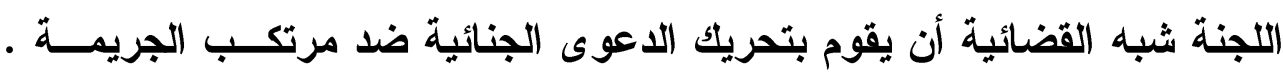

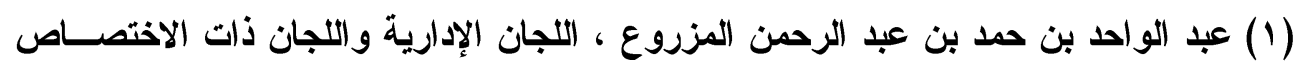

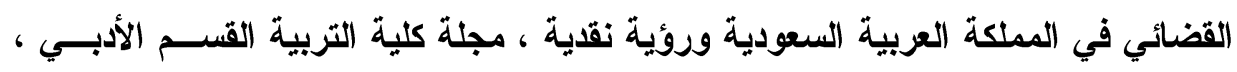

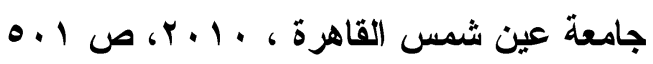


وللإجابة على هذا التساؤل فإنتا يجب أولا الخوض في ماهية تلك اللجــان شـبة

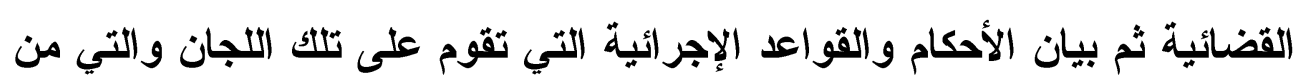

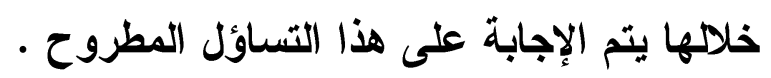

\section{" ماهية الاجان شبة القضائية في الملككة العربية السعودية :-}

عرف الفقه اللجان شبه القضائية في المملكــة العربيــة الســودية بأنهــا مجموعة من المختصين - خارج السلك القضائي - ومهمتها النظر فــي قضــــايا التأديب أو جزاء أو تسوية منازعات مدنية أو تجارية محددة بموجب نظام معتمد

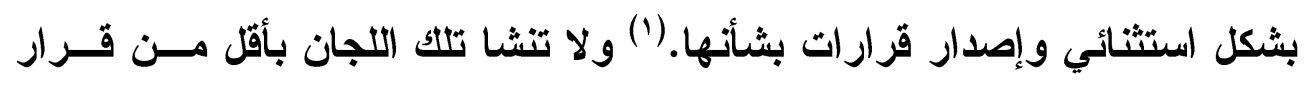
وزاري. (r)

وأنتا لن نتحدث في هذا المقام عن إثكالية عيوب نظام اللجان القضائية بـلـل

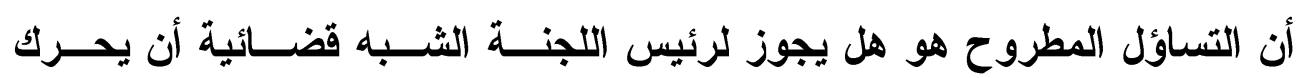

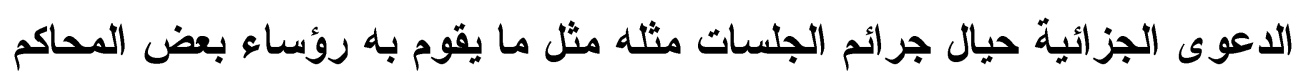

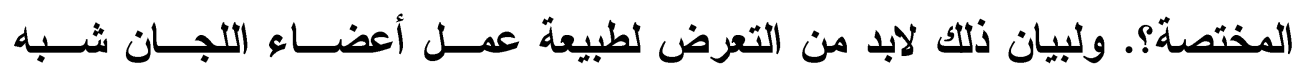
القضائية وإجراءات تسيير العمل أمام تلك اللجان.

هناك نظرية وضعت معيار اللتمييز بين العمل القضائي وغيره ، وهو معيـار

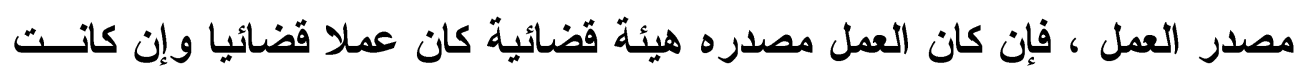

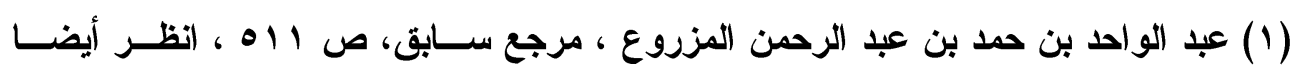

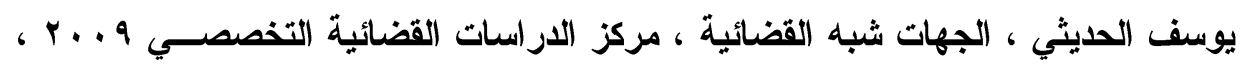

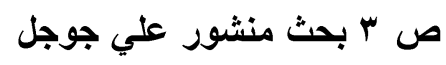

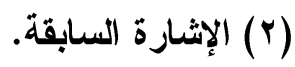


إحدى السلطات التنفيذية هي المصدر الأي يستمد منه هذا العمل وجوده كان عملا

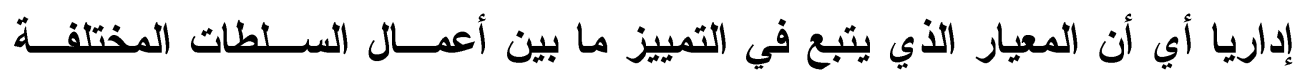

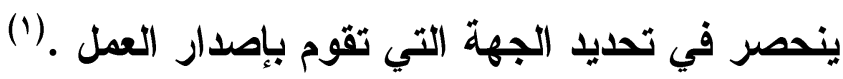

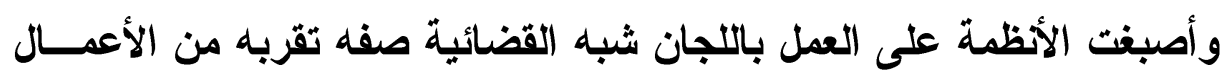

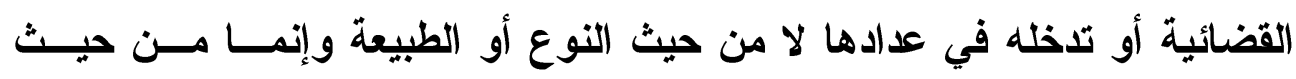

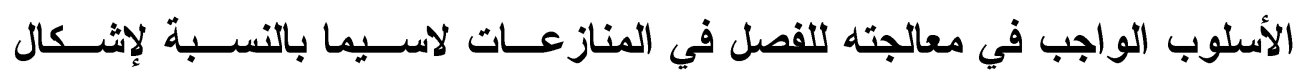

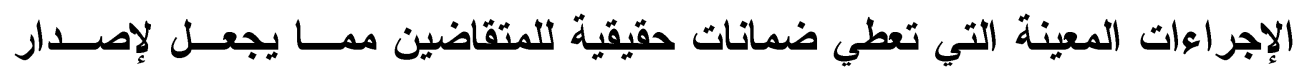

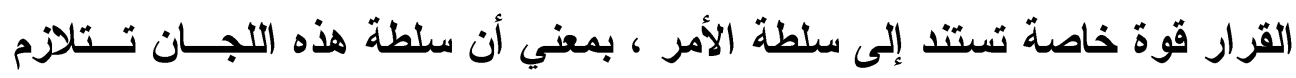

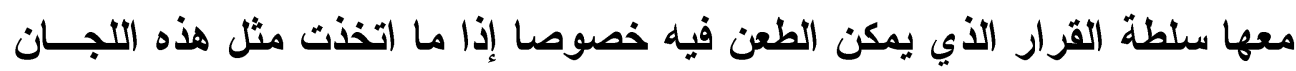

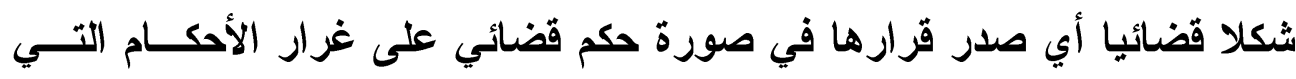

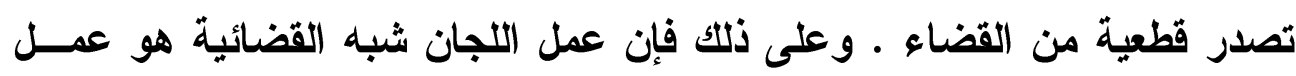

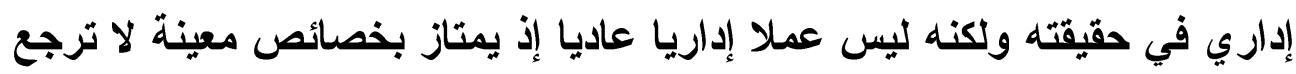
إلى طبيعته بل إلى مصدره فهو عمل ذو طبيعة مزدوجة يسفر عنه تنفيذ ما أناط

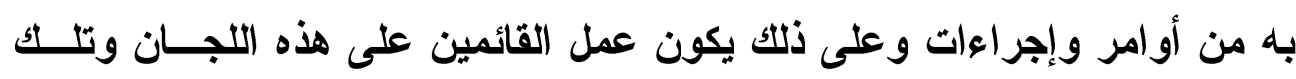

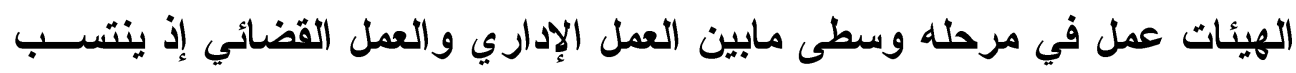

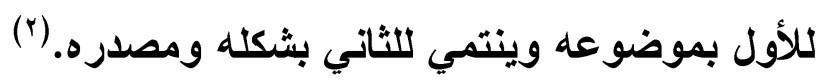

(1) وجدي راغب ، النظرية العامة للعمل القضائي في قانون المر افعـات ، ط 1 ا ـ ب ، شــأن

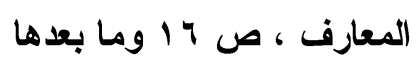

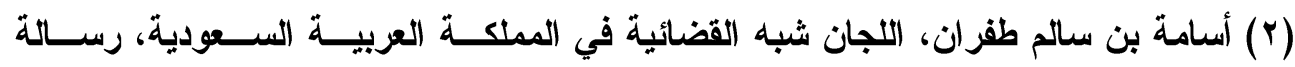

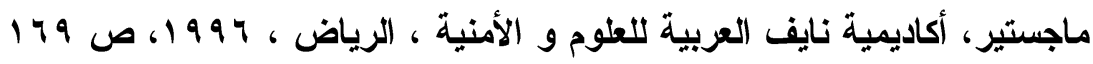




\section{* النظام الإجراني المبق أمام الجان ثبه القضانية :-}

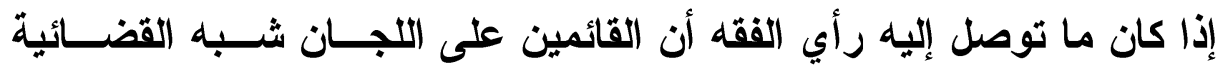

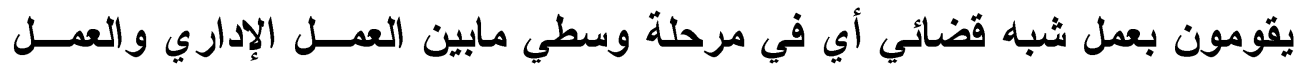

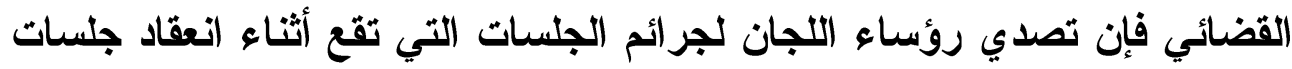

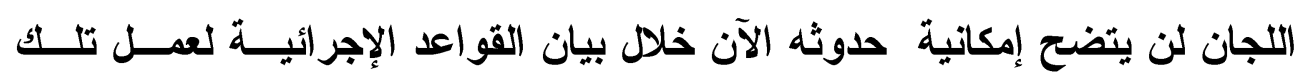

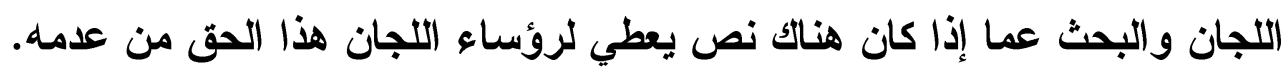

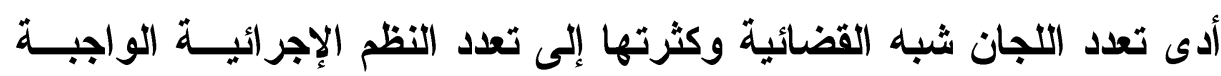

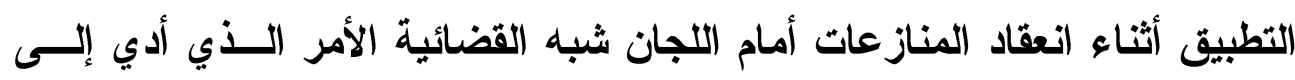

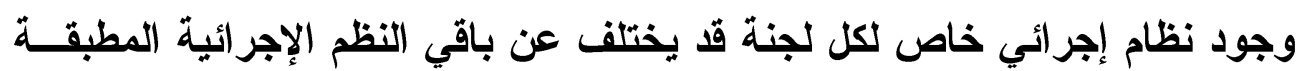

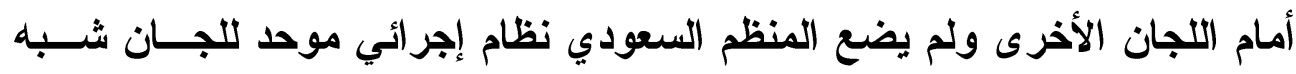

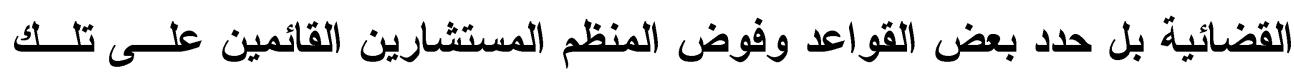

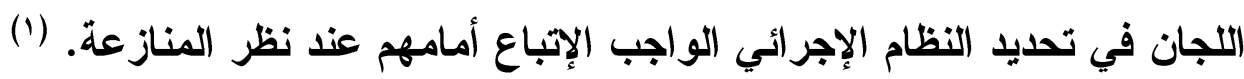

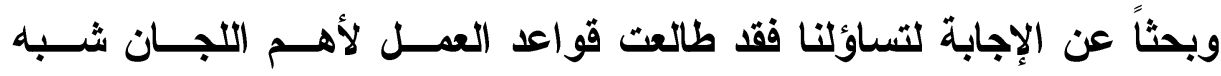

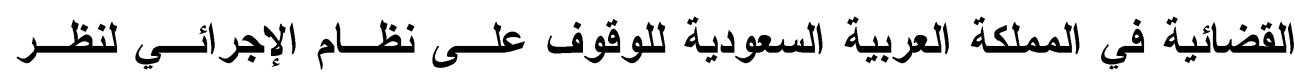

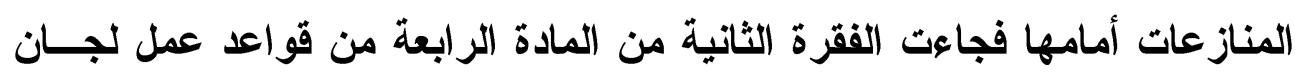
الفصل في المخالفات والمنازعات المصرفية تنص على أنه " تطبق اللجنتين نظام

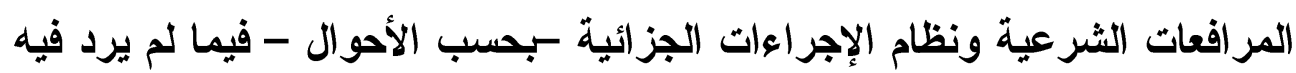
نص في هذه القواعد ، وبما لا يتعارض مع اختصاصــات وصــلاحيات وطبيعـة

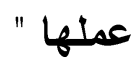

(1) أسامة بن سالم طقران، مرجع سابق ، ص 0 V 
وجاعت المادة 11 من قواعد عمل لجنة الفصل في منازعات الأوراق المالية

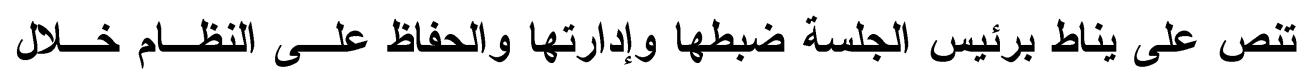

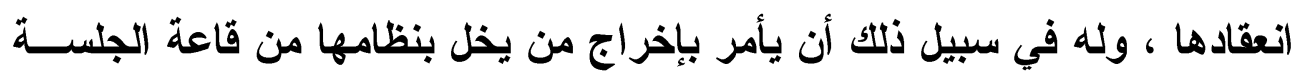

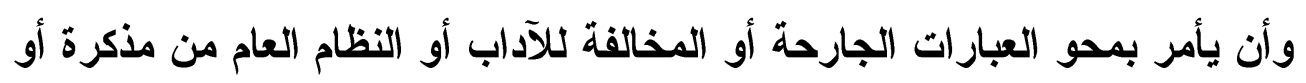

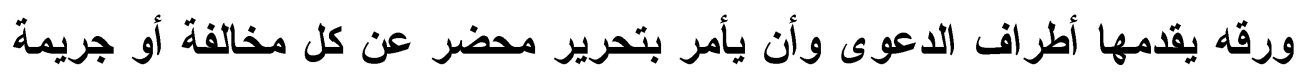

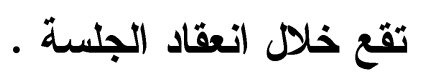

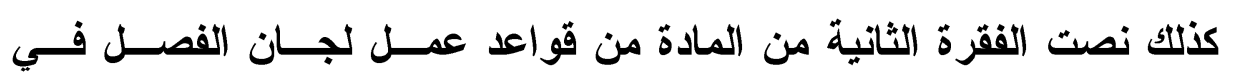

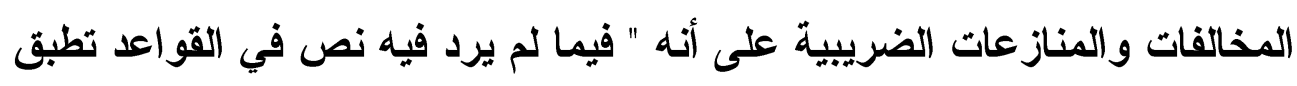

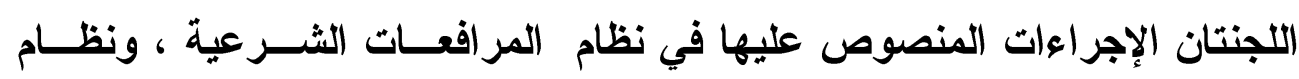

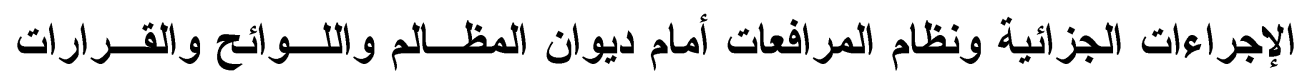

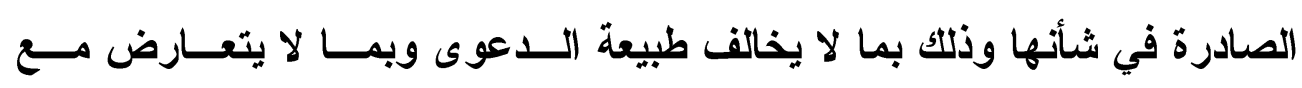
اختصاصات اللجنتين وصلاحيتهما وطبيعة عملهما .

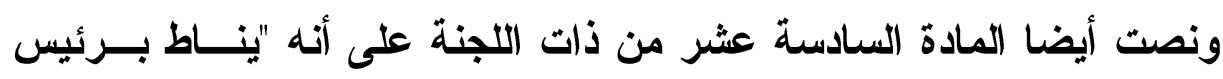

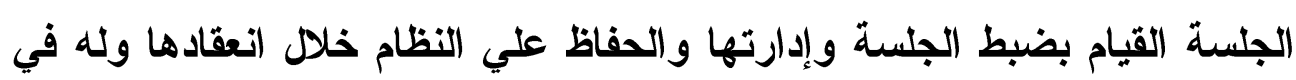

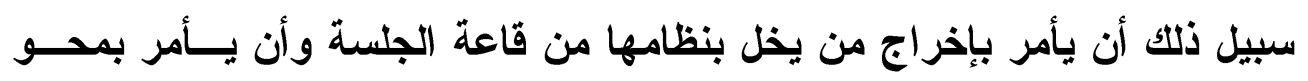

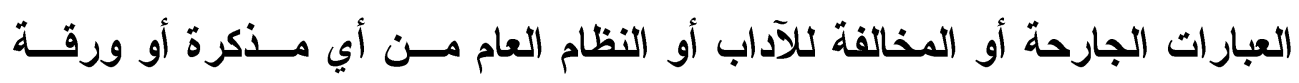

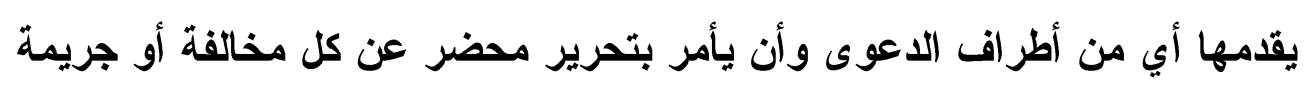

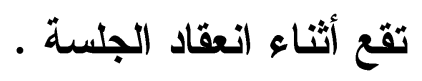
وكذلك جاءت قواعد عمل اللجان الجمركية بما نصت عليه قو اعد عمل لجان الفصل في المنازعات الضريبية . 
و المطالع لنصوص المواد سالفة البيان يجد أنها حوت علــى نــوعيين مـنـ

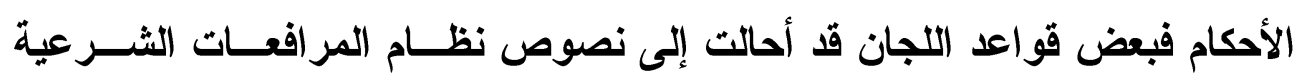

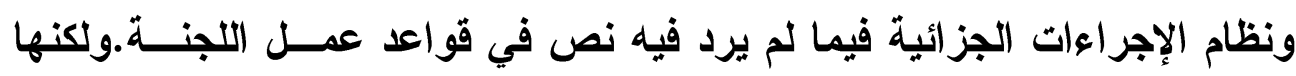

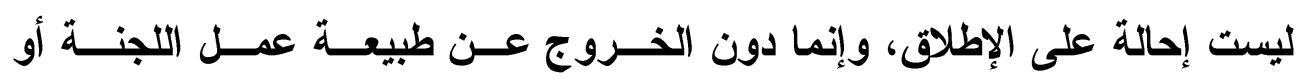

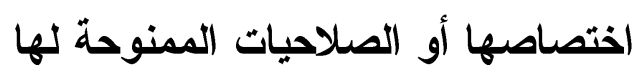

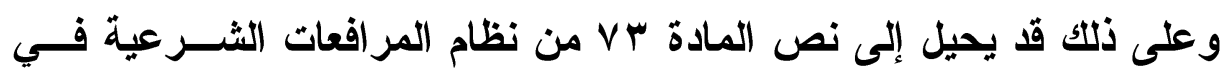

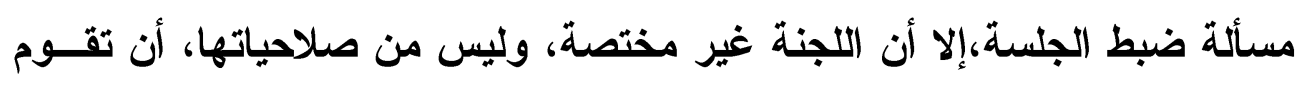

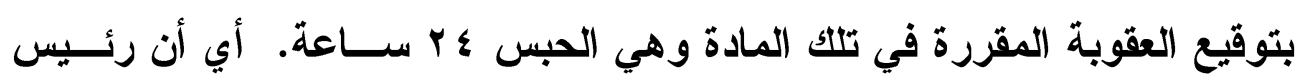

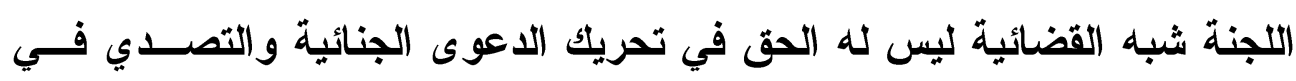
جرائم التشويش والإخلال بنظام الجلسة.

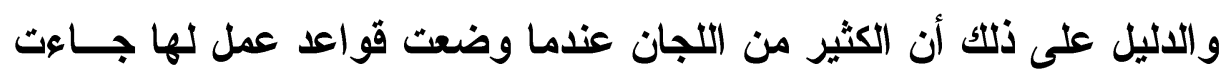

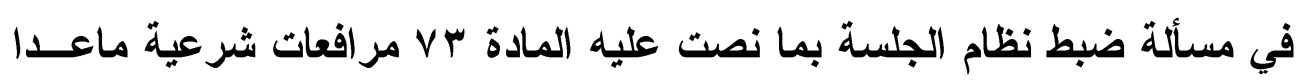

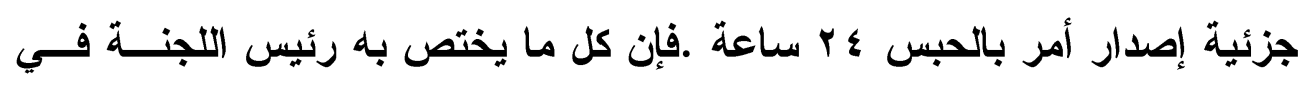

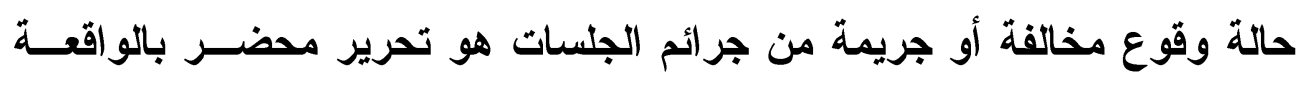

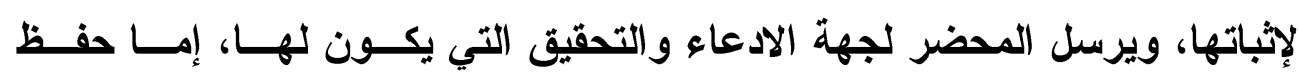
المحضر ، أو تحريك الاعوى الجنائية .

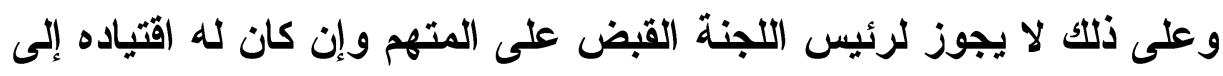
مركز الثرطة أو التّفظظ عليه لحين حضور مأموري الضبط القضائي .

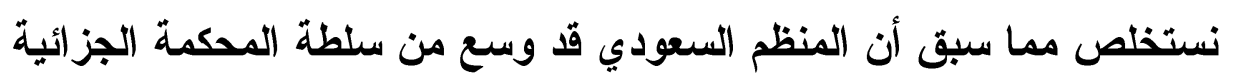

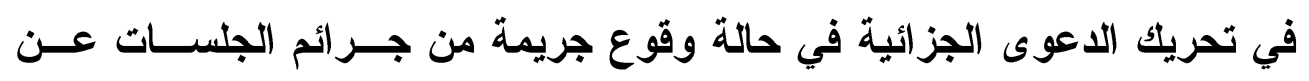

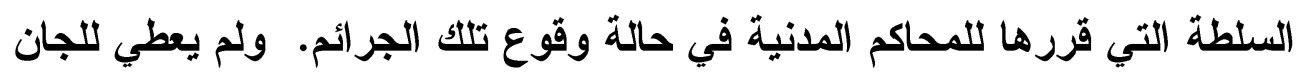


شبه القضائية سلطة تحريك الدعوى الجزائية في حالة جرائم الجلسات أو التصدي

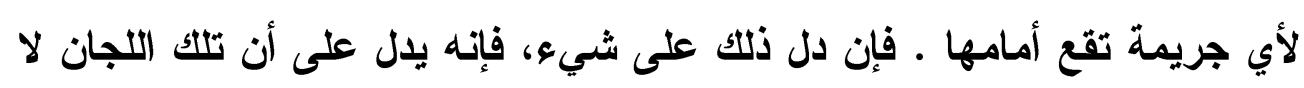

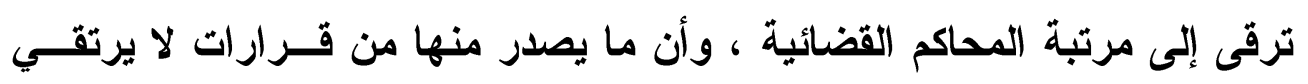

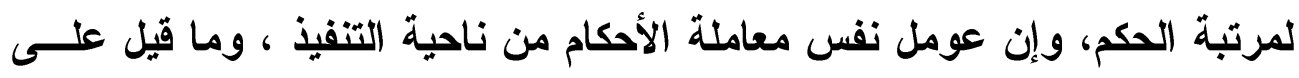

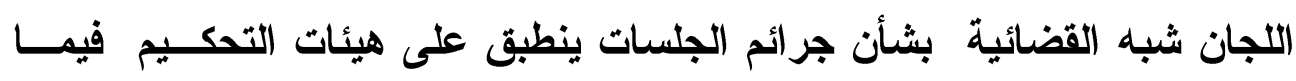

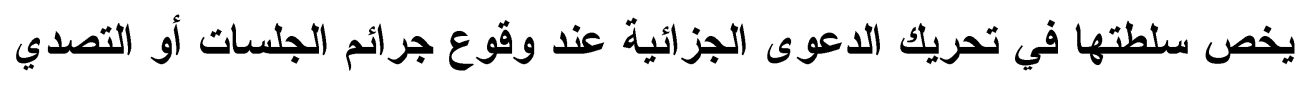

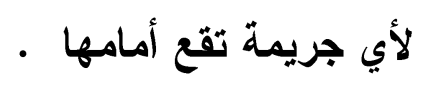




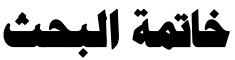

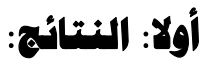

\section{توملت الدراسة موضوع البمث إلى عدة نتائج نجملها فيما يالي:}

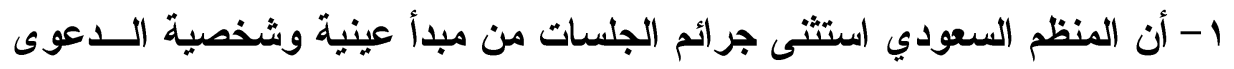

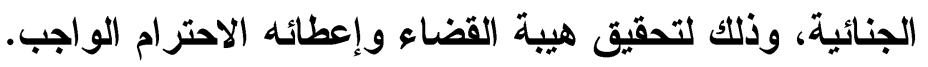

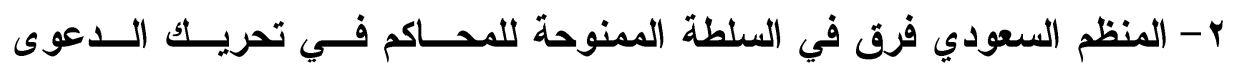

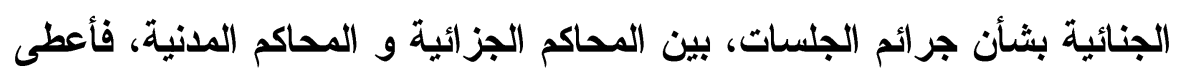

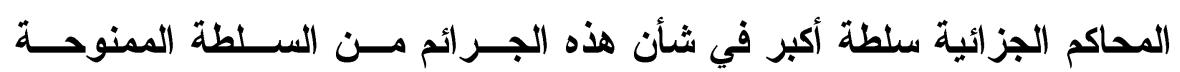

\section{لاكحاكم المدنية.}

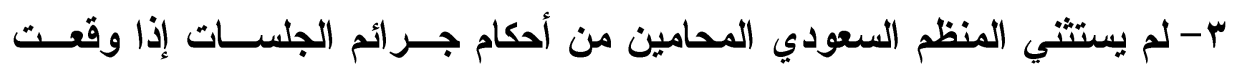

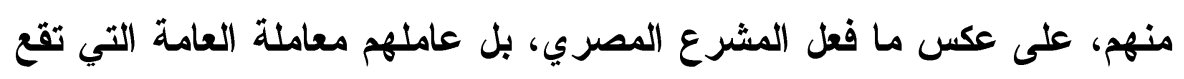
منهم جرائم الجلسات دون أي خصوصية أو ضمانات أو تمييز.

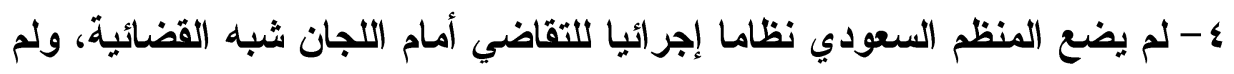

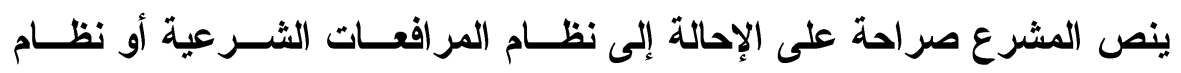

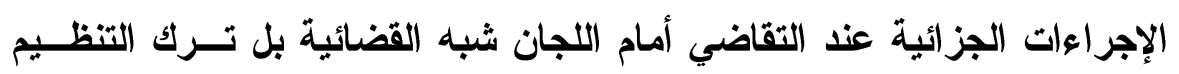

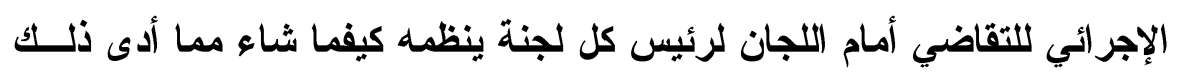
إلى تعدد تلك التنظيمات. هـ - لم يعطي المنظم السعودي الحق لرئيس اللجنة شبه القضائية أو رئسيس هيئسـة

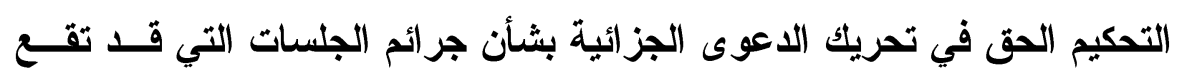

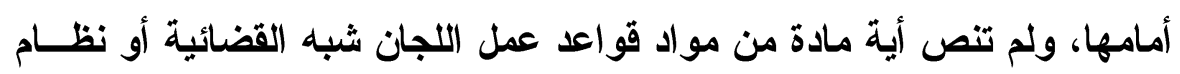

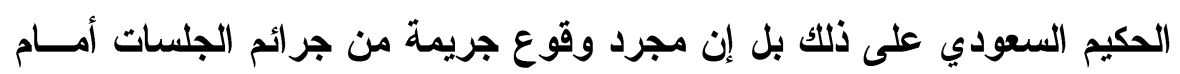

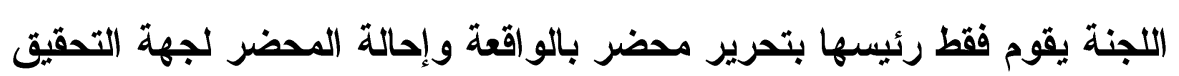

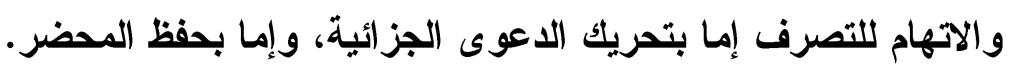


ثانيا: التوصيات:

\section{وعلى إثر هذه النتائج يوصي البامث المنظم السعودي بما يلي:}

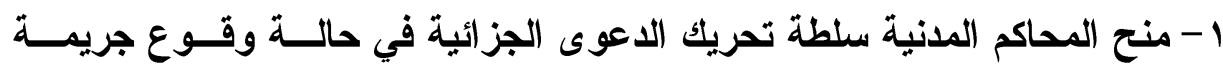

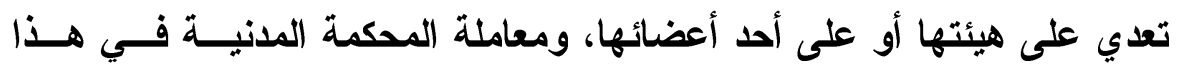
الثأن معاملة المحاكم الجزائية. r- استثناء المحامين من أحكام جرائم الجلسات ووضع لهم أحكام خاصة بهم فـي

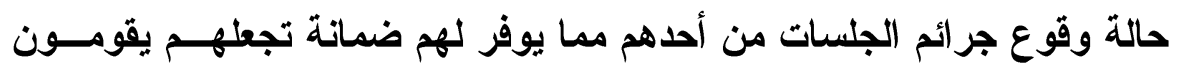
بالدور المخول لهم وتقديم رسالة الافاع عن الحق وتحقيق العدالة بحرية وبغير قيود أسوة بالمشرع المصري في هذا الثأن. r- وضع نظام إجرائي واضح وموحد للتقاضي أمام اللجان شبه القضائية، وعـدم فئد ترك ذللك لرئيس اللجنة. فالقضاة في المحاكم يلتزمون بأحكام الأظظمة الإجرائية

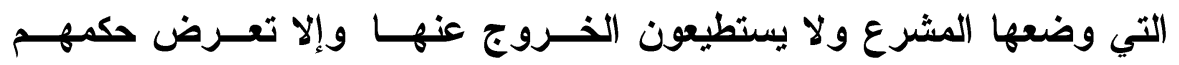

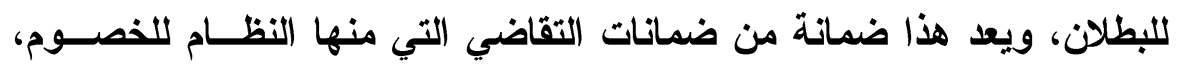
فكيف يكون لرئيس اللجنة شبه القضائية الحق في تحديــــ النظــام الإجرائسي هي

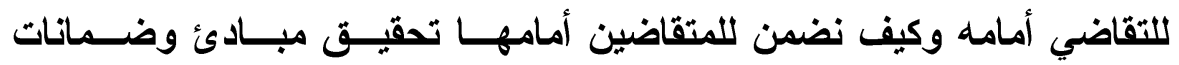
التقاضي التي نصت عليها الأظمة الإجرائية. ع - عدم منح اللجان شبه القضائية ولجان التحكيم أية سلطات بثأن تحريك الاعوى الإنه

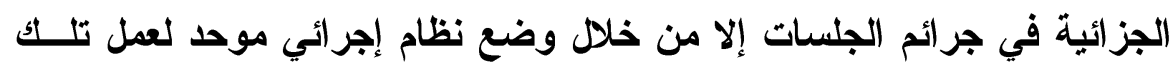
اللجان نضمن فيه للخصوم تطبيق مبادئ المر افعات وضمانات التقاضــي أمسـام المحاكم. 


\section{المراجع (المات}

• آمال عثمان ، شرح قانون الإجراعات الجنائية ، الهيئة المصرية العامــة

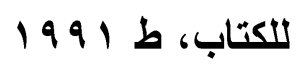

احمد فتحي سرور ، الوسيط في قانون الإجــراءات الجنائيسـة ، الكتـــاب

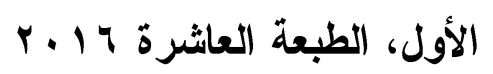

احمد أبو الوفا ، نظرية الأحكام في قانون المرافعات، دار الفكر العربي، ط

$$
r+1 r
$$

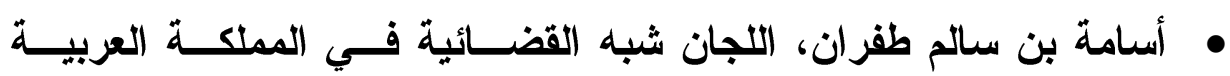

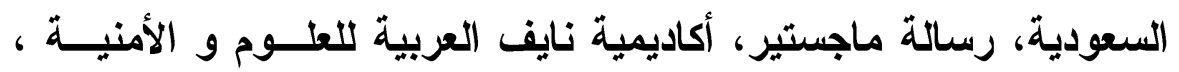

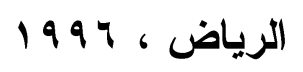

ايمن فاروق عبد المعبود حمد، الأحكام الإجرائية لجرائم الجلسات التــي

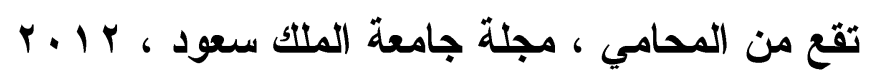

رؤوف عبيد، مبادئ الإجراعات الجنائية في القانون المصــري، مطبعـة

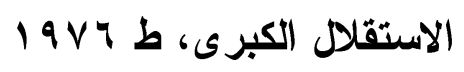

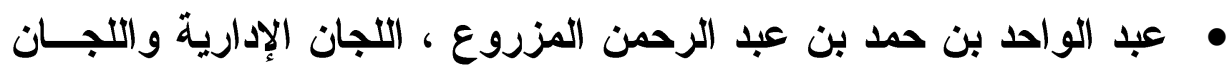

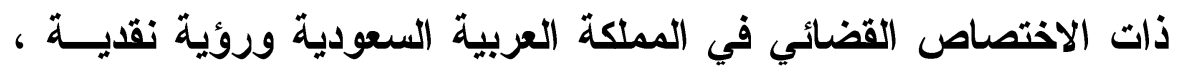

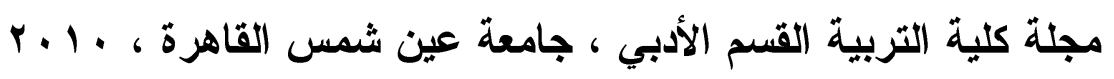

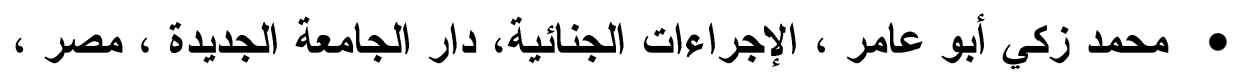

$$
\text { r... }
$$

• وجدي راغب ، النظرية العامة للعمل القضائي في قانون المرافعـات ، ط

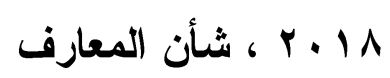


• يوسف الحديثي ، الجهات شبه القضائية ، مركــز الدراســات القضــائية

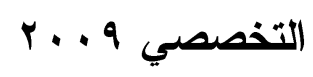

• موقع مركز الار اسات القضائية التخصصيwww.cojss.com

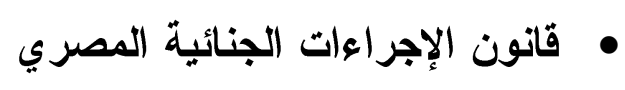

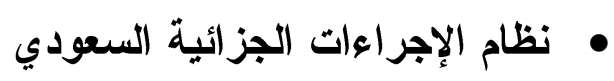

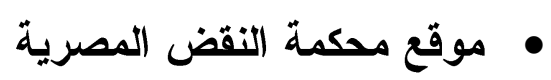


فهرس الموضوعات

\begin{tabular}{|c|c|}
\hline |لصفمة & الإوضوع \\
\hline$r \cdot r q$ & \\
\hline$r \cdot \varepsilon \cdot$ & السعودي والبـث الأول:أحكام جرائم الجلسات أمام القضاء الجزائي في النظــام \\
\hline$r \cdot \varepsilon$. & 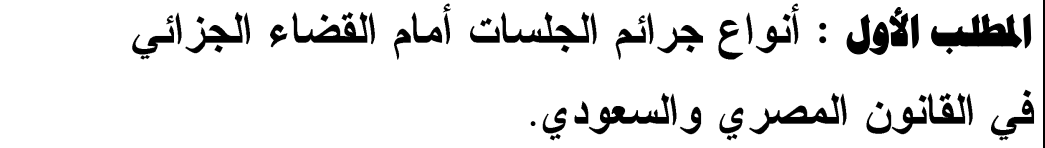 \\
\hline$r .01$ & الاملب الثاني : وقوع جرائم الجلسات من المحاميين. \\
\hline$r \cdot 0 \leq$ & المبمث الثاني : أحكام جرائم الجلسات أمام القاضي المدني • \\
\hline$r .00$ & المطب الأول : جرائم الجلسـات أمام القضاء المدني فـي القــانون \\
\hline$Y . T$. & 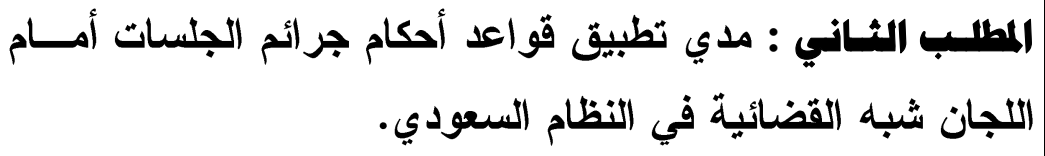 \\
\hline$r \cdot 7 V$ & الخاتمة. \\
\hline$r .79$ & المادر والمراجع . \\
\hline$r \cdot V_{1}$ & فهرس الموضومات \\
\hline
\end{tabular}

